\title{
Hydrogen Sulfide and Persulfides Oxidation by Biologically Relevant Oxidizing Species
}

\author{
Dayana Benchoam 1,2, Ernesto Cuevasanta 1,2,3, Matías N. Möller ${ }^{2,4}$ and Beatriz Alvarez ${ }^{1,2, *}$ \\ 1 Laboratorio de Enzimología, Instituto de Química Biológica, Facultad de Ciencias, \\ Universidad de la República, Montevideo 11400, Uruguay; dbenchoam@fcien.edu.uy (D.B.); \\ ecuevasanta@fcien.edu.uy (E.C.) \\ 2 Center for Free Radical and Biomedical Research, Universidad de la República, Montevideo 11800, Uruguay; \\ mmoller@fcien.edu.uy \\ 3 Unidad de Bioquímica Analítica, Centro de Investigaciones Nucleares, Facultad de Ciencias, \\ Universidad de la República, Montevideo 11400, Uruguay \\ 4 Laboratorio de Fisicoquímica Biológica, Instituto de Química Biológica, Facultad de Ciencias, \\ Universidad de la República, Montevideo 11400, Uruguay \\ * Correspondence: beatriz.alvarez@fcien.edu.uy
}

Received: 22 January 2019; Accepted: 19 February 2019; Published: 22 February 2019

\begin{abstract}
Hydrogen sulfide $\left(\mathrm{H}_{2} \mathrm{~S} / \mathrm{HS}^{-}\right)$can be formed in mammalian tissues and exert physiological effects. It can react with metal centers and oxidized thiol products such as disulfides (RSSR) and sulfenic acids (RSOH). Reactions with oxidized thiol products form persulfides (RSSH/ RSS $^{-}$). Persulfides have been proposed to transduce the signaling effects of $\mathrm{H}_{2} \mathrm{~S}$ through the modification of critical cysteines. They are more nucleophilic and acidic than thiols and, contrary to thiols, also possess electrophilic character. In this review, we summarize the biochemistry of hydrogen sulfide and persulfides, focusing on redox aspects. We describe biologically relevant one- and two-electron oxidants and their reactions with $\mathrm{H}_{2} \mathrm{~S}$ and persulfides, as well as the fates of the oxidation products. The biological implications are discussed.
\end{abstract}

Keywords: hydrogen sulfide; persulfide; hydropersulfide; reactive oxygen species; sulfiyl radical

\section{Hydrogen Sulfide: An Ancient Metabolite with Novel Regulatory Roles}

Hydrogen sulfide $\left(\mathrm{H}_{2} \mathrm{~S}\right)$ is the simplest molecule containing reduced sulfur among the wide diversity of sulfur compounds. It was first synthesized as a gas, and its composition was identified in the eighteenth century [1]. It is naturally occurring in geothermal sources [2] and has been related to the emergence and evolution of organisms in Earth [3]. It is a crucial molecule in the metabolism of several organisms, acting both as an electron donor in energetic pathways (anoxygenic photosynthesis and oxidative phosphorylation in lithotrophs [4]) and as a sulfur donor in synthetic pathways (cysteine and methionine synthesis, among others [5]). Furthermore, sulfur- and sulfate-reducing organisms are able to produce $\mathrm{H}_{2} \mathrm{~S}$ in assimilative or dissimilative processes [6].

$\mathrm{H}_{2} \mathrm{~S}$ was identified as a toxic compound for humans centuries ago. High levels of $\mathrm{H}_{2} \mathrm{~S}$ can induce inhibition of cellular respiration [7]. Exposure of mammals to $\mathrm{H}_{2} \mathrm{~S}$ from sewage, industrial sources and domestic accidents have produced numerous cases of loss of consciousness and death [8]. However, some animals are able to tolerate elevated levels of $\mathrm{H}_{2} \mathrm{~S}$ and have efficient systems for its detoxification [9]. Indeed, in the human intestine, mitochondria are able to deal with the $\mathrm{H}_{2} \mathrm{~S}$ produced by the enteric flora [10], which diffuses easily through membranes [11-13] and represents a hazard for neighboring tissues. The enterocytes are able to fuel the electronic transport chain by oxidizing $\mathrm{H}_{2} \mathrm{~S}$ to sulfate $\left(\mathrm{SO}_{4}{ }^{2-}\right)$ and thiosulfate $\left(\mathrm{S}_{2} \mathrm{O}_{3}{ }^{2-}\right)$ [14]. The discovery of endogenous biogenesis of $\mathrm{H}_{2} \mathrm{~S}$ in mammals $[15,16]$ and the evidence of modulatory effects when administered 
at low concentrations led to the hypothesis of a regulatory role [17-19]. Numerous physiological responses to $\mathrm{H}_{2} \mathrm{~S}$ have been reported since, including interactions with several cation channels in the nervous system, the attenuation of myocardial ischemia reperfusion injury, promotion of angiogenesis, and the induction of pro-/anti-inflammatory responses [20]. Several reports assigned an antioxidant role for $\mathrm{H}_{2} \mathrm{~S}$, which could be related to cytoprotective effects [21-26]; nevertheless, consideration of the kinetics of the reactions suggests that the protective role is not due to direct reactions of $\mathrm{H}_{2} \mathrm{~S}$ with oxidants, as will be described below [27].

\section{Persulfides as Potential Transducers of $\mathrm{H}_{2} \mathrm{~S}$ Signaling}

The observed physiopathological effects focused the research in the field on the identification of cellular targets and on the underlying signaling mechanisms in order to develop plausible routes for pharmacological intervention. $\mathrm{H}_{2} \mathrm{~S}$ shows nucleophilicity and is analogous to thiols, albeit weaker $[27,28]$. Among some possible targets in cells, $\mathrm{H}_{2} \mathrm{~S}$ can react with metallic centers (iron, copper, zinc, molybdenum) producing coordination complexes and, in some circumstances, donating electrons. $\mathrm{H}_{2} \mathrm{~S}$ is also able to react with oxidized forms of protein thiols such as disulfides (RSSR) or sulfenic acids (RSOH), thus leading to the formation of persulfides (RSSH/RSS ${ }^{-}$) $[28,29]$.

The persulfides, which are also intermediates in the synthesis of particular sulfur biomolecules [30,31], are nowadays being considered candidate species for the transduction of the signals triggered by $\mathrm{H}_{2} \mathrm{~S}$. Not only are these species suggested to be more nucleophilic and acidic than the original thiols, but they also show an electrophilic character that is lacking in the original thiols [32]. In addition, enzymatic pathways for the $\mathrm{H}_{2} \mathrm{~S}$-independent formation of persulfides have been reported [33-42]. The generation of persulfides on critical protein cysteines constitutes a posttranslational modification which could affect relevant activities in cells $[43,44]$ and thus allow for signal transduction and the modulation of processes. Furthermore, persulfides are able to react with oxidants. Direct and indirect protective effects of persulfides have been hypothesized and possible antioxidant roles are being surveyed [45-48].

The biochemistry of $\mathrm{H}_{2} \mathrm{~S}$ and persulfides is now under intense scrutiny. In this work we describe the characteristics of these species from a redox biochemistry perspective, focusing on the reactions of $\mathrm{H}_{2} \mathrm{~S}$ and persulfides with reactive species of biological interest.

\section{Chemistry and Biology of $\mathrm{H}_{2} \mathrm{~S}$}

$\mathrm{H}_{2} \mathrm{~S}$ is recognized by its odor of rotten eggs. Humans can detect as low as $0.0005-0.3 \mathrm{ppm}$, whereas concentrations higher than $10 \mathrm{ppm}$ start to cause discomfort and higher than $500 \mathrm{ppm}$ cause rapid loss of consciousness and death [49].

The recommended names by IUPAC are dihydrogen sulfide and sulfane for $\mathrm{H}_{2} \mathrm{~S}$, and sulfanide or

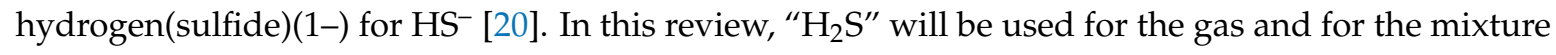
of $\mathrm{H}_{2} \mathrm{~S}$ and $\mathrm{HS}^{-}$in aqueous solution.

$\mathrm{H}_{2} \mathrm{~S}$ may be considered at first sight to be similar to water, but there are several important differences that lead to dissimilar physical and chemical properties. Sulfur is larger than oxygen (van der Waals radii of 1.80 and $1.42 \AA$, respectively) [50], has a lower electronegativity (2.58 and 3.44 in the Pauling scale, respectively), and is more polarizable [51]. Hence, the dipole moment of $\mathrm{H}_{2} \mathrm{~S}$ is lower than that of water, and hydrogen bonds in $\mathrm{H}_{2} \mathrm{~S}$ are not formed at room temperature [51]; this explains why $\mathrm{H}_{2} \mathrm{~S}$ is a gas at ambient temperature and pressure. $\mathrm{H}_{2} \mathrm{~S}$ can dissolve in water with a relatively high solubility $\left(101.3 \mathrm{mM} / \mathrm{atm}\right.$ at $\left.25^{\circ} \mathrm{C}\right)$ [52], and the solvation is dominated by dispersive forces with no hydrogen bonds with water [51]. The slightly hydrophobic character of $\mathrm{H}_{2} \mathrm{~S}$ is further supported by its twice higher solubility in organic solvents such as octanol and hexane than in water [12].

$\mathrm{H}_{2} \mathrm{~S}$ is a weak diprotic acid with $\mathrm{pK} K_{\mathrm{a} 1}=6.98$ at $25^{\circ} \mathrm{C}$ and 6.76 at $37^{\circ} \mathrm{C}$ (Equation 1) [53]. The second $\mathrm{pK} K_{\mathrm{a} 2}$ has been more difficult to determine exactly but lies between 17 and 19 (Equation 2) in aqueous solution at $25^{\circ} \mathrm{C}[20,53]$. Therefore, $\mathrm{S}^{2-}$ concentrations will be very low in biological settings and will 
not contribute significantly to $\mathrm{H}_{2} \mathrm{~S}$ reactivity. At $\mathrm{pH} 7.4$ and $25{ }^{\circ} \mathrm{C}$, total sulfide exists $28 \%$ as $\mathrm{H}_{2} \mathrm{~S}, 72 \%$ as $\mathrm{HS}^{-}$, and as insignificant amounts of $\mathrm{S}^{2-}$.

$$
\begin{aligned}
& \mathrm{H}_{2} \mathrm{~S} \rightleftharpoons \mathrm{HS}^{-}+\mathrm{H}^{+} \\
& \mathrm{HS}^{-} \rightleftharpoons \mathrm{S}^{2-}+\mathrm{H}^{+}
\end{aligned}
$$

The hydrophobic character of $\mathrm{H}_{2} \mathrm{~S}$ results in a higher solubility in membrane lipids than in water that results in a rapid diffusion through cell membranes without assistance by protein channels [11-13]. Permeability coefficients are estimated to be larger than $0.5 \mathrm{~cm} / \mathrm{s}$ and probably larger than $10 \mathrm{~cm} / \mathrm{s}$ [11-13], which indicates that membranes could slow down $\mathrm{H}_{2} \mathrm{~S}$ diffusion 10-100 times compared to an equally thick layer of water. This is a low barrier that does not impede free diffusion across cellular membranes and only becomes significant when considering diffusion across a large number of membranes such as in a tissue [12].

The oxidation state of sulfur in $\mathrm{H}_{2} \mathrm{~S}$ and in $\mathrm{HS}^{-}$is -2 . Thus, $\mathrm{H}_{2} \mathrm{~S}$ can only be oxidized; it cannot act as an oxidant. Therefore, the statements in the literature regarding $\mathrm{H}_{2} \mathrm{~S}$ oxidation of protein cysteines to persulfides are not correct; either the thiol or $\mathrm{H}_{2} \mathrm{~S}$ need to have undergone previous oxidation for cysteine persulfide formation to occur. Oxidation of $\mathrm{H}_{2} \mathrm{~S}$ can lead to various products in which the sulfur can have oxidation numbers up to +6 . The oxidation products include sulfate $\left(\mathrm{SO}_{4}{ }^{2-}\right)$, sulfite $\left(\mathrm{SO}_{3}{ }^{2-}\right)$, thiosulfate $\left(\mathrm{S}_{2} \mathrm{O}_{3}{ }^{2-}\right)$, persulfides $\left(\mathrm{RSS}^{-}\right)$, organic $\left(\mathrm{RSS}_{\mathrm{n}} \mathrm{SR}\right)$ and inorganic $\left(\mathrm{HSS}_{\mathrm{n}} \mathrm{S}^{-}\right)$ polysulfides, and elemental sulfur $\left(\mathrm{S}_{\mathrm{n}}\right)$.

\subsection{Biological Sources of $\mathrm{H}_{2} \mathrm{~S}$}

Mammals obtain reduced sulfur from cysteine and methionine in the diet. The latter is an essential amino acid, but cysteine can be synthesized from methionine through the transsulfuration pathway. Two proteins involved in this metabolic pathway, cystathionine $\beta$-synthase (CBS) and cystathionine $\gamma$-lyase (also called $\gamma$-cystathionase, CSE), can produce $\mathrm{H}_{2} \mathrm{~S}$. Another enzyme from sulfur metabolism, 3-mercaptopyruvate sulfurtransferase (MST), also produces $\mathrm{H}_{2} \mathrm{~S}[20,32]$.

The canonical reaction of CBS is the $\beta$-replacement of L-serine by L-homocysteine to generate L-cystathionine and $\mathrm{H}_{2} \mathrm{O}$, but CBS also catalyzes other reactions using alternative substrates such as cysteine instead of serine that leads to cystathionine and $\mathrm{H}_{2} \mathrm{~S}$ [54]. Mutations in this protein are the most common cause of hereditary homocystinuria [55]. CSE catalyzes the $\gamma$-elimination of cystathionine to give cysteine, $\alpha$-ketobutyrate, and ammonia, but, like CBS, can also catalyze other reactions that lead to formation of $\mathrm{H}_{2} \mathrm{~S}$, such as the $\beta$-elimination of cysteine that is estimated to be the major reaction involved in $\mathrm{H}_{2} \mathrm{~S}$ synthesis by CSE [54]. MST catalyzes the transfer of the sulfur atom from 3-mercaptopyruvate to a nucleophilic acceptor such as thioredoxin or glutathione (GSH), which subsequently releases $\mathrm{H}_{2} \mathrm{~S}$ [56].

There are some differences in tissue distribution and subcellular localization. CSE is considered a cytosolic protein that predominates in cardiovascular tissue and liver; CBS is also cytosolic and is considered an important source of $\mathrm{H}_{2} \mathrm{~S}$ in the nervous system; MST has been found both in the cytosol and the mitochondria and is the other important source of $\mathrm{H}_{2} \mathrm{~S}$ in the nervous system [20].

\subsection{Biological Sinks of $\mathrm{H}_{2} \mathrm{~S}$}

There are several mechanisms that decompose $\mathrm{H}_{2} \mathrm{~S}$. The main pathway for $\mathrm{H}_{2} \mathrm{~S}$ detoxification is located in the mitochondria and involves oxidation of sulfide to sulfate and thiosulfate [20]. The enzyme sulfide quinone oxidoreductase (SQR) oxidizes $\mathrm{H}_{2} \mathrm{~S}$ and reduces coenzyme $\mathrm{Q}$. An intermediate SQR-persulfide is formed and transferred either to glutathione to make glutathione persulfide (GSSH) or to sulfite to form thiosulfate. GSSH is subsequently metabolized by persulfide dioxygenase (PDO, also called ethylmalonic encephalopathy protein 1, ETHE1) to glutathione and sulfite $\left(\mathrm{SO}_{3}{ }^{2-}\right)$, and the latter is oxidized to sulfate $\left(\mathrm{SO}_{4}{ }^{2-}\right)$ by sulfite oxidase. Rhodanese could use 
GSSH and sulfite to make thiosulfate. Alternatively, thiosulfate could be utilized by rhodanese to produce GSSH [57-59].

$\mathrm{H}_{2} \mathrm{~S}$ also reacts with ferric hemoglobin and myoglobin (methemoglobin and metmyoglobin, respectively) through a complex mechanism that results in the formation of thiosulfate and iron-bound polysulfides [60,61]. Though the proportion of methemoglobin is usually below $1 \%$ [62], the concentration of total hemoglobin subunits in red blood cells is $20 \mathrm{mM}$, and thus up to $200 \mu \mathrm{M}$ methemoglobin may be available to react with $\mathrm{H}_{2} \mathrm{~S}$. Besides, several medications and diseases are known to increase methemoglobin [62], so this may be an important sink for $\mathrm{H}_{2} \mathrm{~S}$ in circulation. Furthermore, in the presence of oxygen or hydrogen peroxide, $\mathrm{H}_{2} \mathrm{~S}$ can modify hemes covalently in these globins and some other hemeproteins, thus forming green sulfheme in which the sulfur is covalently bound to one pyrrole ring. These processes will be further analyzed in Section 4.2.6.

\subsection{Physiology and Pharmacology of $\mathrm{H}_{2} \mathrm{~S}$}

Although early studies indicated that physiological concentrations of $\mathrm{H}_{2} \mathrm{~S}$ in different tissues were in the 30-100 $\mu \mathrm{M}$ range, improved detection methods suggest that actual concentrations are in the 4-55 nM range for most tissues [63-66].

Externally added $\mathrm{H}_{2} \mathrm{~S}$ at higher concentrations has been observed to have different effects. In the cardiovascular system, $\mathrm{H}_{2} \mathrm{~S}$ has multiple nitric oxide-dependent and independent effects that include the relaxation of smooth muscle cells, regulation of blood pressure, promotion of angiogenesis, and attenuation of myocardial ischemia reperfusion injury [19,67-72]. In the nervous system, $\mathrm{H}_{2} \mathrm{~S}$ is considered to be a neuromodulator. For example, it affects hippocampal long-term potentiation [18]. It has also been shown to inhibit $\mathrm{HOCl}$ - and peroxynitrite-mediated toxicity in neuroblastoma cells $[21,23]$. Moreover, $\mathrm{H}_{2} \mathrm{~S}$ protects neurons from oxidative stress by increasing $\gamma$-glutamylcysteine synthetase activity and cystine transport, which induces the production of reduced glutathione [22]. In the respiratory system, $\mathrm{H}_{2} \mathrm{~S}$ has potential therapeutic uses against fibrosis and chronic obstructive pulmonary disease $[73,74]$. In the liver, a hepatoprotective effect of $\mathrm{H}_{2} \mathrm{~S}$ has been observed against ethanol-induced liver injury in mice [75].

$\mathrm{H}_{2} \mathrm{~S}$ has shown both pro- and anti-inflammatory effects. In sepsis and acute pancreatitis, a pro-inflammatory effect of $\mathrm{H}_{2} \mathrm{~S}$ has been observed [76-78], whereas an anti-inflammatory effect has been reported for intestinal ischemic damage and ethanol-induced gastritis [79-81].

The antioxidant effects cannot be attributed to direct reactions with oxidants since, from a kinetic perspective, $\mathrm{H}_{2} \mathrm{~S}$ may not be able to trap oxidative species, as rationalized below. The indirect mechanisms underlying the observed antioxidant effects may be various. For example, $\mathrm{H}_{2} \mathrm{~S}$ was proposed to inhibit oxidative stress through the persulfidation of Keap1, which activates nuclear factor (erythroid-derived 2)-like 2 (Nrf2) signaling and promotes its translocation to the nucleus and the expression of antioxidant pathways [75,82-85].

\section{Oxidizing Species in Biology and Their Reactions with $\mathrm{H}_{2} \mathrm{~S}$}

The formation of partial oxygen reduction products can occur in biological systems. These free radical and non-free radical species are superoxide radical $\left(\mathrm{O}_{2} \bullet^{-}\right)$, hydrogen peroxide $\left(\mathrm{H}_{2} \mathrm{O}_{2}\right)$, and hydroxyl radical $(\mathrm{HO} \bullet)$. Together with secondary species such as peroxynitrite $\left(\mathrm{ONOO}^{-}\right)$, hypochlorous acid $(\mathrm{HOCl})$, or organic peroxyl radicals $(\mathrm{ROO} \bullet)$, they are in general called reactive oxygen species (ROS); however, this term should be used with caution because it gives the erroneous idea that there is only one ill-defined species that oxidizes all biomolecules. In contrast, the reactivity of the oxidants varies, and their targets in biological settings are determined by kinetic aspects of rate constants multiplied by the concentration of the potential target as well as compartmentalization and membrane permeability aspects. The different species can be divided into two-electron or one-electron oxidants. The latter are often free radicals that start oxygen-dependent chain reactions.

One important site of reactive species formation is the mitochondrial electron transport chain. They can also be formed by ionizing and UV radiation, through the redox cycling of certain xenobiotics, 
and enzymatically through the action of NADPH oxidases, xanthine oxidase, hemeperoxidases, and cytochromes P450. Nitric oxide synthase generates nitric oxide, which, by itself, is not highly oxidizing, but it can react with superoxide radical generating peroxynitrite and secondary oxidants derived from it.

The high reactivity of some of these species with biomolecules can lead to cell damage; this aspect is exploited by immune cells in their warfare against microorganisms. Oxidant action can be counteracted, in some cases, by antioxidants; for example, in the free radical process of lipid peroxidation, peroxyl radical intermediates can be scavenged by the antioxidant vitamins $\mathrm{E}$ and $\mathrm{C}$. In addition to their cell damaging action, oxidants can have signaling roles, as becomes clear from the evidence for the actions of hydrogen peroxide as a second messenger [86]. Thus, the classical concept of oxidative stress as a disbalance between oxidant formation and antioxidant action has been extended to include the concept of a disbalance in regulatory pathways.

In the following paragraphs, we briefly describe the oxidants potentially involved in the two- and one-electron oxidation of $\mathrm{H}_{2} \mathrm{~S}$, we provide the rate constants of the reactions, and we discuss the fate of some of the products formed. The reactions are summarized in Scheme 1.

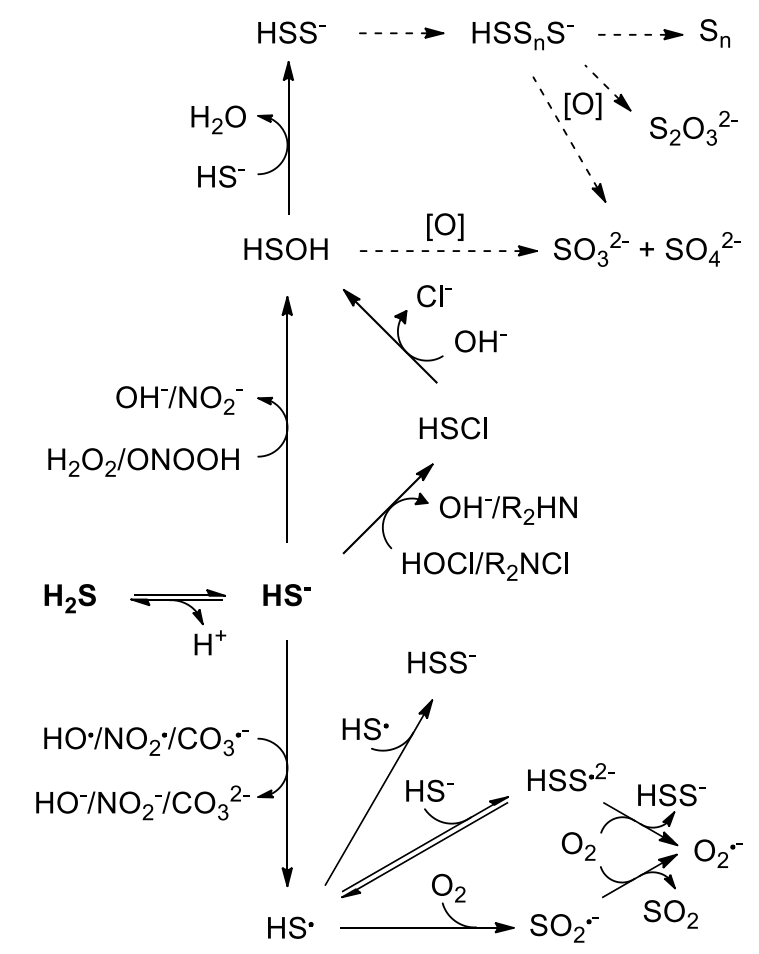

Scheme 1. Hydrogen sulfide oxidation by reactive species. The dashed lines represent processes that are accomplished in more than one step. Protons are sometimes omitted for simplicity.

\subsection{Two-Electron Oxidation}

$\mathrm{H}_{2} \mathrm{~S}$ is a strong reductant according to the two-electron reduction potential $E^{\circ}\left(\mathrm{HSS}^{-}, \mathrm{H}^{+} / 2 \mathrm{HS}^{-}\right)$ $=-0.23 \mathrm{~V}[87,88]$. The disulfide HSSH $/$ HSS $^{-}$is not formed directly but in at least two steps. Rather, sulfenic acid ( $\mathrm{HSOH}$ ) is formed, an unstable intermediate that reacts fast with a second $\mathrm{H}_{2} \mathrm{~S}$ to form $\mathrm{HSSH} / \mathrm{HSS}^{-}$. The latter is also unstable and can disproportionate yielding polysulfides of different chain lengths, elemental sulfur and $\mathrm{H}_{2} \mathrm{~S}$. Polysulfides can also react with reductants or be oxidized to oxyacids. Several two-electron oxidants can react with $\mathrm{H}_{2} \mathrm{~S}$.

\subsubsection{Hydrogen Peroxide}

This two-electron oxidant $\left(E^{\circ}\left(\mathrm{H}_{2} \mathrm{O}_{2}, 2 \mathrm{H}^{+} / 2 \mathrm{H}_{2} \mathrm{O}\right)=+1.35 \mathrm{~V}\right)$ [89] is formed mainly by the dismutation of superoxide radical, which can be spontaneous or catalyzed by superoxide dismutases. 
It can also be formed directly by some oxidases. Though it is a strong oxidant, hydrogen peroxide reacts relatively slowly with most biomolecules, with the exception of peroxidases containing selenocysteine, cysteine or heme. Accordingly, the reaction between $\mathrm{H}_{2} \mathrm{~S}$ and hydrogen peroxide has a rate constant of $0.73 \mathrm{M}^{-1} \mathrm{~s}^{-1}$ at $\mathrm{pH} 7.4$ and $37^{\circ} \mathrm{C}$ [27]. The primary product is $\mathrm{HSOH}$. The final products depend on the initial ratios of hydrogen peroxide to $\mathrm{H}_{2} \mathrm{~S}$ and consist mainly of polysulfides, elemental sulfur and, in the presence of excess oxidant, sulfate. Curiously, the system can behave like a chemical oscillator $[90,91]$.

\subsubsection{Hypochlorous Acid and Chloramines}

Hypochlorous acid $(\mathrm{HOCl})$ is formed from the oxidation of chloride ions by the neutrophil enzyme myeloperoxidase. $\mathrm{HOCl}$ is a highly oxidizing species $\left(E^{\circ}\left(\mathrm{HClO}, \mathrm{H}^{+} / \mathrm{Cl}^{-}, \mathrm{H}_{2} \mathrm{O}\right)=+1.28 \mathrm{~V}\right)$ [92] and reacts fast with $\mathrm{HS}^{-}$with a second order rate constant of $0.8-20 \times 10^{8} \mathrm{M}^{-1} \mathrm{~s}^{-1}$ at $\mathrm{pH} 7.4$ [27,93]. Hypochlorous acid usually reacts by transferring a $\mathrm{Cl}^{+}$species to a nucleophile. Thus, the reaction with $\mathrm{HS}^{-}$is likely to proceed through the formation of $\mathrm{HSCl}$, which quickly hydrolyzes to $\mathrm{HSOH}$. The hypochlorite ion is in equilibrium with hypochlorous acid ( $\mathrm{p} K_{\mathrm{a}}$ 7.47). Hypochlorite can also react with $\mathrm{HS}^{-}$, albeit several orders of magnitude more slowly [93]. At an excess of $\mathrm{H}_{2} \mathrm{~S}$ with respect to hypochlorous acid, the main product formed is elemental sulfur, with the intermediacy of polysulfides [93].

The reaction of hypochlorous acid with amines leads to chloramines ( $\mathrm{RHNCl}$ and $\mathrm{R}_{2} \mathrm{NCl}$ ). These are less reactive and more selective oxidants than hypochlorous acid. Taurine chloramine reacts with $\mathrm{H}_{2} \mathrm{~S}$ with a rate constant of $3 \times 10^{2} \mathrm{M}^{-1} \mathrm{~s}^{-1}$ at $\mathrm{pH} 7.4$ and $37^{\circ} \mathrm{C}$ [27].

\subsubsection{Peroxynitrite}

This anion $\left(\mathrm{ONOO}^{-}\right)$and its conjugate acid, peroxynitrous acid $(\mathrm{ONOOH}, \mathrm{pK}$ a 6.8), are formed from the reaction of superoxide radical with nitric oxide, which occurs at nearly diffusion controlled rates. Peroxynitrous acid is unstable and can decay in buffer to nitric acid, hydroxyl radical, and nitrogen dioxide. In vivo, peroxynitrite can either react directly with targets such as thiols or metal centers, or it can react with carbon dioxide, leading to the formation of the secondary radicals, nitrogen dioxide and carbonate radical [94]. Peroxynitrous acid reacts directly with $\mathrm{HS}^{-}$with a second order rate constant of $6.7 \times 10^{3} \mathrm{M}^{-1} \mathrm{~s}^{-1}\left(\mathrm{pH} 7.4,37^{\circ} \mathrm{C}\right.$ ) [95] and, after a short lag, yellow products are formed [96]. According to computational simulations, the process starts with the nucleophilic substitution of $\mathrm{HS}^{-}$on $\mathrm{ONOOH}$ to give $\mathrm{HSOH}$ and $\mathrm{NO}_{2}^{-}$as initial products. In the presence of excess $\mathrm{H}_{2} \mathrm{~S}, \mathrm{HSOH}$ reacts with a second $\mathrm{HS}^{-}$to yield $\mathrm{HSS}^{-} / \mathrm{HSSH}$. It was proposed that the yellow products originate from the secondary reaction of $\mathrm{HSS}^{-} / \mathrm{HSSH}$ with peroxynitrite, and that at least one of the yellow products is $\mathrm{HSNO}_{2}$ or its isomer HSONO [95].

In addition to the direct reaction of peroxynitrous acid with $\mathrm{HS}^{-}$, the free radicals derived from peroxyinitrite decay can also react with $\mathrm{H}_{2} \mathrm{~S}$ and trigger oxygen dependent chain reactions that can be evidenced, for example, by the consumption of oxygen [27].

\subsection{One-Electron Oxidation}

The one-electron reduction potential of $\mathrm{H}_{2} \mathrm{~S}$ is $\left(E^{\circ}\left(\mathrm{HS} \bullet, \mathrm{H}^{+} / \mathrm{H}_{2} \mathrm{~S}\right)=+0.91-0.94 \mathrm{~V}\right)[87,97]$. This value means that, in principle, only relatively strong one-electron oxidants such as hydroxyl radical $\left(\mathrm{HO}^{\bullet}\right)$, carbonate radical $\left(\mathrm{CO}_{3} \bullet^{-}\right)$, nitrogen dioxide $\left(\mathrm{NO}_{2} \bullet\right)$, and peroxidase oxoferryl

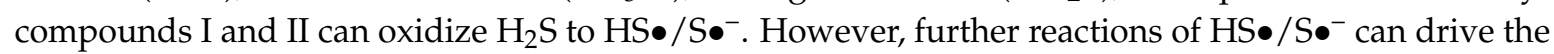
oxidation processes, extending the list of possible initial oxidants to, for example, metal centers with lower one-electron reduction potentials than that of the $\mathrm{HS} \bullet / \mathrm{H}_{2} \mathrm{~S}$ couple.

The initial product of the one-electron oxidation of $\mathrm{H}_{2} \mathrm{~S}$ is the sulfiyl radical $\left(\mathrm{HS} \bullet / \mathrm{S}^{-}\right.$). This is an oxidizing radical and can react with several electron or hydrogen atom donors $(\mathrm{AH}$, Equation 3). In addition, it can react with a second HS•/S•- radical and form $\mathrm{HSSH}^{-} \mathrm{HSS}^{-}$(Equation 4). Alternatively, $\mathrm{HS} \bullet / \mathrm{S} \bullet-$ can react with $\mathrm{HS}^{-}$to form $\mathrm{HSS}_{\bullet}{ }^{2-}$, a reducing radical that can react with 
oxygen forming superoxide radical (Equations 5,6). HS•/S $\bullet^{-}$can also react with oxygen and form $\mathrm{SO}_{2} \bullet^{-}$, which can again react with oxygen to form superoxide radical (Equations 7,8 ). The latter dismutates to hydrogen peroxide and oxygen, which helps to drive the process.

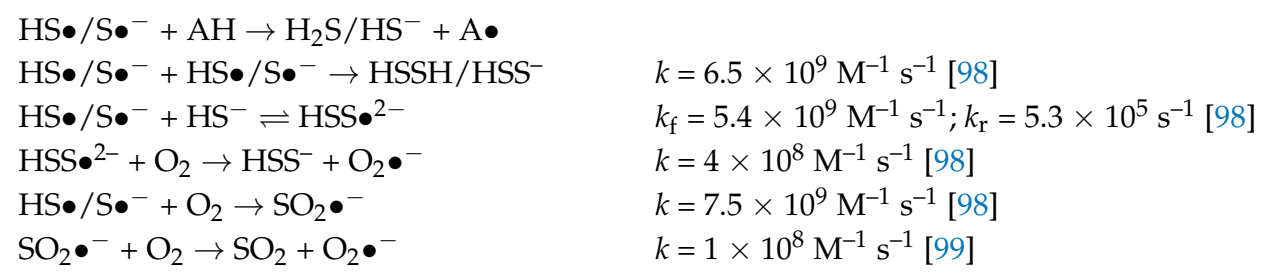

In addition to these relatively well characterized reactions, several other reactions can occur, which lead to a wide variety of possible radical and non-radical products and unstable intermediates. It is clear that the one-electron oxidation of $\mathrm{H}_{2} \mathrm{~S}$ can trigger oxygen-dependent free radical chain reactions that can lead to the amplification of initial oxidation events. Several one-electron oxidants can initiate these events.

\subsubsection{Oxygen}

The one-electron oxidation of $\mathrm{H}_{2} \mathrm{~S}$ by oxygen $\left(\mathrm{O}_{2}\right)$ is thermodynamically uphill, since the $E^{\circ}\left(\mathrm{O}_{2} / \mathrm{O}_{2} \bullet^{-}\right)=-0.35 \mathrm{~V}\left(-0.18 \mathrm{~V}\right.$ for a $1 \mathrm{M} \mathrm{O}_{2}$ standard state) [89]. It is also very slow because of the spin barrier imposed by the diradical character of $\mathrm{O}_{2}$. Nevertheless, $\mathrm{H}_{2} \mathrm{~S}$ autoxidation occurs and is a major concern in practical work with $\mathrm{H}_{2} \mathrm{~S}$. The process is likely driven by the reactivity of the initial products, $\mathrm{HS} \bullet$ and $\mathrm{O}_{2} \bullet^{-}$, as well as that of secondary intermediates. Autoxidation is very slow and dependent on $\mathrm{pH}$. It is critically affected by the presence of trace metal ions that can act as catalysts. It is also mechanistically complex due to the involvement of radical and non-radical intermediates. The products formed are usually elemental sulfur $\left(\mathrm{S}_{\mathrm{n}}\right)$, sulfate $\left(\mathrm{SO}_{4}{ }^{2-}\right)$, sulfite $\left(\mathrm{SO}_{3}{ }^{2-}\right)$, and thiosulfate $\left(\mathrm{S}_{2} \mathrm{O}_{3}{ }^{2-}\right)[100,101]$.

\subsubsection{Superoxide Radical}

This species is the primary free radical formed from the partial reduction of oxygen. Superoxide radical $\left(\mathrm{O}_{2} \bullet^{-}\right)$can dismutate to oxygen and hydrogen peroxide, spontaneously or enzymatically. It can also react with nitric oxide yielding peroxynitrite. This radical can be both oxidizing and reducing, with $E^{\circ}\left(\mathrm{O}_{2} \bullet^{-}, 2 \mathrm{H}^{+} / \mathrm{H}_{2} \mathrm{O}_{2}\right)=+0.91 \mathrm{~V}$ and $E^{\circ}\left(\mathrm{O}_{2} / \mathrm{O}_{2} \bullet^{-}\right)=-0.18 \mathrm{~V}\left(1 \mathrm{M} \mathrm{O}_{2}\right.$ standard state) [89]. It can react with $\mathrm{H}_{2} \mathrm{~S}$ with a rate constant of $\sim 208 \mathrm{M}^{-1} \mathrm{~s}^{-1}$ in dimethyl sulfoxide [102]. However, rather than being scavenged by $\mathrm{H}_{2} \mathrm{~S}$, superoxide radical can be formed in $\mathrm{H}_{2} \mathrm{~S}$ oxidation processes due to free radical chain reactions, as described in Section 4.2.

\subsubsection{Hydroxyl Radical}

The highly oxidizing hydroxyl radical (HO•) is formed in biological systems mainly through the Fenton reaction, i.e., through the reduction of hydrogen peroxide to $\mathrm{HO} \bullet$ and $\mathrm{H}_{2} \mathrm{O}$ by reduced metal ions $\left(\mathrm{Fe}^{2+}\right.$ or $\left.\mathrm{Cu}^{+}\right)$. With a reduction potential of $+2.31 \mathrm{~V}$ at $\mathrm{pH} 7$ [89], hydroxyl radical is so oxidizing that it can react with most biomolecules, and the rate constants are close to the diffusion limit. It can react very fast with both $\mathrm{H}_{2} \mathrm{~S}$ and $\mathrm{HS}^{-}$, according to Equations 9,10 $[98,103]$.

$$
\begin{array}{ll}
\mathrm{HO} \bullet+\mathrm{H}_{2} \mathrm{~S} \rightarrow \mathrm{H}_{2} \mathrm{O}+\mathrm{HS} \bullet & k=1.1 \times 10^{10} \mathrm{M}^{-1} \mathrm{~s}^{-1}[103] \\
\mathrm{HO} \bullet+\mathrm{HS}^{-} \rightarrow \mathrm{HSOH} \bullet^{-} \rightarrow \mathrm{S} \bullet-/ \mathrm{HS} \bullet+\mathrm{H}_{2} \mathrm{O} / \mathrm{OH}^{-} & k=5.4 \times 10^{9} \mathrm{M}^{-1} \mathrm{~s}^{-1}[103]
\end{array}
$$

\subsubsection{Nitrogen Dioxide}

This free radical $\left(\mathrm{NO}_{2} \bullet\right)$ can be formed from the autoxidation of nitric oxide, from the decay of peroxynitrite in the presence of carbon dioxide and from the oxidation of nitrite. It is an oxidizing species with $E^{\circ}\left(\mathrm{NO}_{2} \bullet / \mathrm{NO}_{2}{ }^{-}\right)=+1.04 \mathrm{~V}$ [88]. The reaction between $\mathrm{H}_{2} \mathrm{~S}$ and nitrogen dioxide was 
studied by pulse radiolysis. The rate constant is $3 \times 10^{6} \mathrm{M}^{-1} \mathrm{~s}^{-1}$ at $\mathrm{pH} 6\left(25^{\circ} \mathrm{C}\right)$ and increases at more alkaline $\mathrm{pH}$, suggesting that $\mathrm{HS}^{-}$is the reacting species [27].

\subsubsection{Carbonate Radical}

The formation of carbonate radical $\left(\mathrm{CO}_{3} \bullet^{-}\right)$depends mainly on the decay of peroxynitrite in the presence of carbon dioxide. It also depends on the oxidation of carbon dioxide/bicarbonate by the peroxidase activity of $\mathrm{CuZn}$ superoxide dismutase or by xanthine oxidase [94]. Carbonate radical is a strong one-electron oxidant $\left(E^{\circ}\left(\mathrm{CO}_{3} \bullet^{-}, \mathrm{H}^{+} / \mathrm{HCO}_{3}{ }^{-}\right)=+1.77 \mathrm{~V}\right)$ [88]. It reacts with $\mathrm{H}_{2} \mathrm{~S}$ with a rate constant of $2.0 \times 10^{8} \mathrm{M}^{-1} \mathrm{~s}^{-1}\left(\mathrm{pH} \mathrm{7,20}{ }^{\circ} \mathrm{C}\right.$ ) [97].

\subsubsection{Metal Centers}

Ferric hemeproteins with an open sixth coordination position, such as methemoglobin, metmyoglobin, myeloperoxidase, and catalase, can oxidize $\mathrm{H}_{2} \mathrm{~S}$ [60,61,104-106].

Depending on the protein, either protonated $\mathrm{H}_{2} \mathrm{~S}$ or $\mathrm{HS}^{-}$can bind to ferric heme [107]. The binding is stable enough in some hemeproteins to suggest a function in $\mathrm{H}_{2} \mathrm{~S}$ storage and transport, as in hemoglobin I from Lucina pectinata [108]. In the case of methemoglobin and metmyoglobin, $\mathrm{H}_{2} \mathrm{~S}$ binds quickly and reversibly to ferric heme. Deprotonation leads to a ferric-HS ${ }^{-}$complex that can slowly evolve to ferrous-bound HS•. The latter species can react with a second $\mathrm{H}_{2} \mathrm{~S}$ or with oxygen, which leads to the formation of polysulfides and thiosulfate as products $[60,61,107,109,110]$.

Remarkably, the hexacoordinated protein ferric cytochrome $c$ can also oxidize $\mathrm{H}_{2} \mathrm{~S}$. The process is

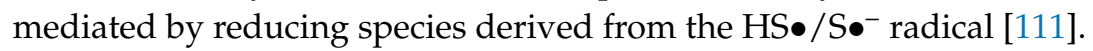

The oxoferryl compounds I and II of myeloperoxidase are formed in the peroxidase cycle of the enzyme and have reduction potentials of +1.35 and $+0.97 \mathrm{~V}$ [92]. They can react with $\mathrm{H}_{2} \mathrm{~S}$ with rate constants of $1 \times 10^{6} \mathrm{M}^{-1} \mathrm{~s}^{-1}$ and $2.0 \times 10^{5} \mathrm{M}^{-1} \mathrm{~s}^{-1}$, respectively ( $\mathrm{pH} 7.4$ and $25^{\circ} \mathrm{C}$ ). Ferric myeloperoxidase can also oxidize $\mathrm{H}_{2} \mathrm{~S}$ and is reduced to the ferrous state [105]. Under aerobic conditions, compound III (ferric-superoxide or ferrous-dioxygen complexes in resonance) is formed. This compound slowly evolves to the ferric enzyme, allowing the enzyme to turnover. Myeloperoxidase-catalyzed oxidation of $\mathrm{H}_{2} \mathrm{~S}$ leads to the formation of polysulfides and protein persulfides [106].

In many cases, the interaction between a hemeprotein and $\mathrm{H}_{2} \mathrm{~S}$ leads to the formation of sulfheme, where one of the pyrroles in the porphyrin ring is covalently modified with a sulfur atom. Such modification has been reported for some globins, lactoperoxidase, and catalase [112]. Many details need to be filled in regarding the mechanism of sulfheme formation. An adequately positioned histidine in the distal heme site has been proposed to be critical [112]. It has also been proposed that, in the case of myeloperoxidase, the presence of a sulfonium ion linkage between a methionine and the heme ring determines that, in contrast to lactoperoxidase, the sulfheme cannot be formed [106]. Computational simulations suggest that sulfheme formation occurs through a concerted interaction between the distal histidine, $\mathrm{H}_{2} \mathrm{~S}$, and a ferric-bound hydroperoxide to form oxoferryl compound II, $\mathrm{H}_{2} \mathrm{O}$ and $\mathrm{HS} \bullet$; the latter subsequently adds to a specific pyrrole site [113].

In addition to hemeproteins, $\mathrm{CuZn}$ and $\mathrm{Mn}$ superoxide dismutases are able to catalyze the oxidation of $\mathrm{H}_{2} \mathrm{~S}$ by oxygen $[114,115]$.

\subsection{Other Oxidants}

Along with the species described above, other oxidants of biological relevance are likely to react with $\mathrm{H}_{2} \mathrm{~S}$, by analogy to their reactions with thiols. Among these other oxidants, organic hydroperoxides, other hypohalous acids such as $\mathrm{HOBr}$ and $\mathrm{HOSCN}$, and free radicals such as peroxyl and phenoxyl radicals are to be considered. 


\subsection{Nitric Oxide}

The crosstalk between nitric oxide and $\mathrm{H}_{2} \mathrm{~S}$ is complex and can give rise to species that contain both $\mathrm{S}$ and $\mathrm{N}$ atoms. Among these, thionitrous acid (HSNO) and perthionitrite $\left(\mathrm{S}_{2} \mathrm{NO}^{-}\right)$have received particular attention $[20,116-121]$.

\subsection{Biological Implications of $\mathrm{H}_{2} \mathrm{~S}$ Oxidation by Reactive Species}

At the physiological $\mathrm{pH}$ of 7.4, the rate constants of the reactions of $\mathrm{H}_{2} \mathrm{~S}$ with oxidants have similar values as those of typical biological thiols such as cysteine and glutathione [27]. The $\mathrm{pH}$-independent rate constants corresponding to the HS species are lower than those of the thiolates species $\left(\mathrm{RS}^{-}\right)$, probably due to the lack of the inductive effect of the methylene. However, the higher acidity of $\mathrm{H}_{2} \mathrm{~S}$ with respect to thiols ( $\mathrm{pK}$ a of 6.98 for $\mathrm{H}_{2} \mathrm{~S}$ compared to 8.29 for cysteine and 8.94 for glutathione [53,122]), determines a higher availability of the ionized species. The net effect is that the apparent rate constants at physiological $\mathrm{pH}$ are comparable.

To analyze whether $\mathrm{H}_{2} \mathrm{~S}$ can be a scavenger of oxidant species, the rates instead of the rate constants need to be taken into account, i.e., the products of rate constants times concentration. While the rate constants are similar to those of thiols, the concentration of $\mathrm{H}_{2} \mathrm{~S}$ in tissues is considered to be submicromolar and several orders of magnitude lower than that of thiols, which is millimolar, so $\mathrm{H}_{2} \mathrm{~S}$ cannot compete with thiols for oxidants. Similar considerations apply for the comparison between $\mathrm{H}_{2} \mathrm{~S}$ and other oxidant scavengers such as ascorbic acid. Hence, $\mathrm{H}_{2} \mathrm{~S}$ cannot be considered a typical antioxidant scavenger except under exceptional situations that lead to high concentrations such as exogenous administration together with enhanced oxidant production. Other mechanisms are probably underlying the observed antioxidant effects of $\mathrm{H}_{2} \mathrm{~S}$; for example, interference with signaling pathways. Furthermore, the one-electron oxidation of $\mathrm{H}_{2} \mathrm{~S}$ can trigger free radical chain reactions, opening the possibility for pro-oxidant effects of $\mathrm{H}_{2} \mathrm{~S}$.

\section{Chemistry and Biology of Persulfides}

Persulfides (RSSH/ $\mathrm{RSS}^{-}$) are sulfane sulfur compounds, meaning that they have a sulfur atom bound to two sulfurs or to a sulfur and an ionizable hydrogen [123]; the outer sulfur is the sulfane sulfur according to this criterion. RSSH can also be referred to with the terms hydropersulfide or hydrodisulfide. In this text, "persulfide" is used to designate mixtures of RSSH and RSS-. Their chemical properties differ from those of thiols; hydropersulfides are more acidic and can either act as nucleophiles when deprotonated (RSS ${ }^{-}$) or electrophiles when protonated (RSSH). They are formed in biological systems through $\mathrm{H}_{2} \mathrm{~S}$-dependent and independent pathways. It is worth noting that the reaction between $\mathrm{H}_{2} \mathrm{~S}$ and thiols does not occur in the absence of an oxidant.

\subsection{Reactivity of Persulfides}

\subsubsection{Persulfide Acidity}

Protonated persulfides ionize in water and form the corresponding anionic persulfides (Equation 11). Their acidity is predicted to be higher than that of the analogous thiols. Thus, at physiological $\mathrm{pH}$, the anionic species would predominate. For instance, the $\mathrm{p} K_{\mathrm{a}}$ of 2-[(3-aminopropyl)amino]ethane persulfide was estimated to be $6.2 \pm 0.1$, while the $\mathrm{p} K_{\mathrm{a}}$ of the analogous thiol is $7.6 \pm 0.1$ [124].

$$
\mathrm{RSSH} \rightleftharpoons \mathrm{RSS}^{-}+\mathrm{H}^{+}
$$

\subsubsection{Persulfides as Nucleophiles}

Anionic persulfides can act as nucleophiles (Equation 12). This is evidenced by their reactions with thiol alkylating agents such as monobromobimane and iodoacetamide, which yield disulfides. This is also evidenced by their reactions with disulfides such as 5,5-dithiobis(2-nitrobenzoic acid) and 
4,4-dithiodipyridine to produce trisulfides [20,28,33,125-129]. Moreover, persulfides react with twoand one-electron oxidants as discussed in Section 6.

$$
\mathrm{RSS}^{-}+\mathrm{E}^{+} \rightarrow \mathrm{RSSE}
$$

Persulfides have been proposed to have an increased nucleophilicity compared to analogous thiolates $[126,130]$. This can be explained by the alpha effect, namely, the increased reactivity of an atom due to the presence of unshared pairs of electrons in the adjacent atom [131,132]. This effect has been observed in the nucleophilicity of $\mathrm{HOO}^{-}$compared to $\mathrm{HO}^{-}$and $\mathrm{NH}_{2} \mathrm{NH}_{2}$ and $\mathrm{NH}_{2} \mathrm{OH}$ compared to $\mathrm{NH}_{3}$ [131]. The first determination of the alpha effect in persulfides was observed in human serum albumin, in which persulfide has an increased reactivity towards the disulfide 4 -4'-dithiodipyridine compared to the thiolate derivative [28]. The alpha effect, together with the predominance of RSS $^{-}$versus RSSH at physiological $\mathrm{pH}$ due to the relatively high acidity, make persulfides better nucleophiles than thiols.

\subsubsection{Persulfides as Electrophiles}

Protonated persulfides are weak electrophiles. They can react with nucleophiles to give thiols when the outer sulfur is attacked (Equation 13) or $\mathrm{H}_{2} \mathrm{~S}$ when the inner sulfur is attacked (Equation 14). Whether the attack is on one sulfur or the other appears to be determined by steric hindrance $[133,134]$ and by the acidity of the leaving group, with the better leaving group being the one with lower $\mathrm{p} K_{\mathrm{a}}$. Hence, as low molecular weight (LMW) thiols have higher $\mathrm{p} K_{\mathrm{a}}$ s than $\mathrm{H}_{2} \mathrm{~S}$, i.e., the $\mathrm{p} K_{\mathrm{a}}$ of cysteine is 8.29 [122] and the $\mathrm{p} K_{\mathrm{a}}$ of $\mathrm{H}_{2} \mathrm{~S}$ is 6.98 [53], the attack on the inner sulfur would predominate. In protein persulfides formed in acidic cysteines, the attack on the outer sulfur would predominate and restore the reduced protein.

$$
\begin{aligned}
& \mathrm{RSSH}+\mathrm{Nu}^{-} \rightarrow \mathrm{RS}^{-}+\mathrm{NuSH} \\
& \mathrm{RSSH}+\mathrm{Nu}^{-} \rightarrow \mathrm{RSNu}+\mathrm{HS}^{-}
\end{aligned}
$$

The outer sulfur can react with cyanide, thiolates, sulfite [133,135], amines [136], hydroxide [137], and tertiary phosphines $[138,139]$. Persulfides and cyanide react to form the corresponding thiol and thiocyanate, which, in the presence of ferric ions, forms a colored complex that can be quantified spectrophotometrically. This is the basis of the method of cold cyanolysis used to quantify persulfides $[123,140]$.

In the reaction of a persulfide with a thiol, the attack on the outer sulfur constitutes a transpersulfidation reaction. In addition to forming thiol, the sulfane sulfur is transferred and a new persulfide at the attacking thiol is formed (Equation 15). The reactions between persulfides and thiols are plausible to occur in vivo. Intermediate persulfides formed in the proteins MST, SQR, and rhodanese can be transferred to several acceptors including cyanide, sulfite, and thiols [34,57,58,141-144]. Cysteine desulfurases, such as those that participate in the synthesis of iron sulfur clusters, are another example of enzymes transferring the sulfane sulfur to a thiol in specific compounds [145]. The reduction of protein persulfides by thiols could constitute a protective mechanism to avoid irreversible cysteine modifications under oxidative stress $[45,111,146]$. A depersulfidase role for thioredoxin has been suggested. One of the proposed mechanisms involves the transfer of the sulfane sulfur from either LMW or protein persulfides to the nucleophilic cysteine of thioredoxin, which regenerates the original thiol and forms thioredoxin persulfide. Subsequently, $\mathrm{H}_{2} \mathrm{~S}$ and oxidized thioredoxin are formed $[29,147,148]$.

On the other hand, when the inner sulfur of a persulfide is attacked by a thiol, $\mathrm{H}_{2} \mathrm{~S}$ is released and a mixed disulfide is formed (Equation 16) $[125,139,149]$. This mechanism has been suggested for the activation of Nrf2 by Keap1. Keap1 persulfide/Nrf2 was proposed to react with a protein thiolate to form a mixed disulfide and release $\mathrm{H}_{2} \mathrm{~S}$ and $\mathrm{Nrf2}$, inducing its activation to protect neuroblastoma cells from methylglyoxal-induced toxicity [150]. 


$$
\begin{aligned}
& \mathrm{RSSH}+\mathrm{R}^{\prime} \mathrm{S}^{-} \rightleftharpoons \mathrm{RS}^{-}+\mathrm{R}^{\prime} \mathrm{SSH} \\
& \mathrm{RSSH}+\mathrm{R}^{\prime} \mathrm{S}^{-} \rightleftharpoons \mathrm{RSSR}^{\prime}+\mathrm{HS}^{-}
\end{aligned}
$$

\subsubsection{Disproportionation of Persulfides}

Persulfides are highly unstable in aqueous solution, making their study difficult. This is related to their nucleophilic and electrophilic character that facilitate the reactions between them causing spontaneous decay through a disproportionation process. Depending on which sulfur is attacked, different products can be formed. The attack on the outer sulfur generates thiol and hydropolysulfides that evolve to elemental sulfur (Equations 17,18), while the attack on the inner sulfur yields polysulfides and $\mathrm{H}_{2} \mathrm{~S}$ (Equation 19) [137]. The decay products are also likely to depend on steric effects and on the acidity of the leaving groups. For example, cysteine persulfide predominantly decays through the release of $\mathrm{H}_{2} \mathrm{~S}$ instead of cysteine, which has a higher $\mathrm{p} K_{\mathrm{a}}$ [35].

$$
\begin{gathered}
\mathrm{RSSH}+\mathrm{RSS}^{-} \rightleftharpoons \mathrm{RSSS}^{-}+\mathrm{RSH} \\
\mathrm{RSSSH} \rightarrow \mathrm{RSH}+\mathrm{S}_{\mathrm{n}} \\
\mathrm{RSSH}+\mathrm{RSS}^{-} \rightleftharpoons \mathrm{RSSSR}+\mathrm{HS}^{-}
\end{gathered}
$$

\subsection{Biological Sources of Persulfides}

Several processes can give rise to persulfides in biological context; some are dependent on $\mathrm{H}_{2} \mathrm{~S}$ and some are not. These processes are described below. In addition, it was recently proposed that cysteine persulfide can be generated from cysteine via cysteinyl-tRNA synthetase [41].

\subsubsection{Radical Processes}

Sulfiyl (HS•) and thiyl radicals (RS•) could be formed by the reaction of strong one-electron oxidants and $\mathrm{H}_{2} \mathrm{~S}$ or RSH, respectively. These radicals could rapidly react yielding a persulfide (Equation 20). Nevertheless, this reaction is not expected to be relevant in vivo due to the low concentration of radical species. A more likely radical pathway to form persulfides is the formation of

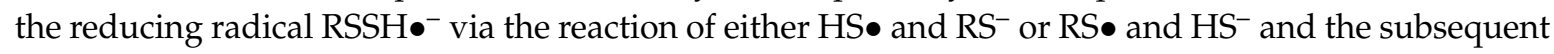
reaction with oxygen (Equations 21-23) [20,151].

$$
\begin{aligned}
& \mathrm{HS} \bullet+\mathrm{RS} \bullet \rightarrow \mathrm{RSSH} \\
& \mathrm{HS} \bullet+\mathrm{RS}^{-} \rightarrow \mathrm{RSSH} \bullet \\
& \mathrm{RS} \bullet+\mathrm{HS}^{-} \rightarrow \mathrm{RSSH}^{-} \\
& \mathrm{RSSH} \bullet^{-}+\mathrm{O}_{2} \rightarrow \mathrm{RSSH}+\mathrm{O}_{2} \bullet^{-}
\end{aligned}
$$

\subsection{2. $\mathrm{H}_{2} \mathrm{~S}$ and Oxidized Thiols}

The reactions of $\mathrm{H}_{2} \mathrm{~S}$ with oxidized thiols constitute biologically significant pathways for the formation of persulfides. $\mathrm{H}_{2} \mathrm{~S}$ can react with disulfides releasing thiol (Equation 24) or with sulfenic acid eliminating water (Equation 25).

$$
\begin{aligned}
& \mathrm{HS}^{-}+\mathrm{RSSR}^{\prime} \rightleftharpoons \mathrm{RSSH}+\mathrm{R}^{\prime} \mathrm{S}^{-} \\
& \mathrm{HS}^{-}+\mathrm{RSOH} \rightarrow \mathrm{RSSH}+\mathrm{OH}^{-}
\end{aligned}
$$

Protein persulfides are formed endogenously through these pathways. For example, a persulfide intermediate of $\mathrm{SQR}$ is formed by the reaction of $\mathrm{H}_{2} \mathrm{~S}$ with the active site disulfide of the enzyme. 
This reaction is $\sim 10^{6}$ fold accelerated compared to the reaction with cystine $[57,58,152]$. In the endoplasmic reticulum, an environment with high concentration of disulfides, the reaction of $\mathrm{H}_{2} \mathrm{~S}$ with disulfides could be more relevant than in compartments with scarce disulfides like the cytosol [151]. In cultured cells, an increase in persulfide concentration was observed after treatment with $\mathrm{H}_{2} \mathrm{O}_{2}$ that led to an increase in sulfenic acid and disulfide. However, this was not observed upon treatment with diamide that only increased disulfide concentration, which suggests that persulfide was formed by $\mathrm{H}_{2} \mathrm{~S}$ and sulfenic acid [28,29]. The reaction of $\mathrm{H}_{2} \mathrm{~S}$ with sulfenic acids could be a mechanism of protection against its overoxidation to sulfinic acid $\left(\mathrm{RSO}_{2} \mathrm{H}\right)$ and sulfonic acid $\left(\mathrm{RSO}_{3} \mathrm{H}\right)$, which are irreversible modifications. On the contrary, the oxidation of persulfidated residues leads to $\mathrm{RSSO}_{2} \mathrm{H}$ and $\mathrm{RSSO}_{3} \mathrm{H}$ species that can be reduced to thiols restoring the protein $[20,29,45,46,153]$.

The reactions of $\mathrm{H}_{2} \mathrm{~S}$ with disulfides and sulfenic acids are common strategies to prepare persulfides in the laboratory. Mixtures of LMW disulfides and $\mathrm{H}_{2} \mathrm{~S}$ have been used as sources of persulfides $[28,66,126,154,155]$. However, the facts that reaction $(24)$ is reversible and that the persulfides formed can react with disulfides to form trisulfides and thiols, need to be taken into account $[128,129]$. The kinetics of the reactions between $\mathrm{H}_{2} \mathrm{~S}$ and LMW disulfides such as cystine, glutathione disulfide, homocystine, and 5,5'-dithiobis-(2-nitrobenzoic acid) to form LMW persulfides are slower than the reactions of thiols with disulfides [28]. The incubation of $\mathrm{H}_{2} \mathrm{~S}$ and mixed disulfides of protein cysteines and acidic LMW thiols has been used to produce persulfides in papain [126], glutathione peroxidase Gpx3 [125], and albumin [28]. The reaction of protein sulfenic acid with $\mathrm{H}_{2} \mathrm{~S}$ has also been used to prepare persulfides in albumin [28,151].

\subsubsection{Thiolates and Oxidized Sulfur Derivatives}

Thiolates and oxidized sulfur derivatives of $\mathrm{H}_{2} \mathrm{~S}$ react to form persulfides. As described previously, the attack of thiolates on the outer sulfur of persulfides produces a new persulfide at the attacking thiolate (Equation 15). For example, the persulfide intermediate formed in SQR has been proposed to react with different molecules. When it reacts with a thiol, a new persulfide is generated [42,58]. In addition, organic and inorganic polysulfides $\left(\mathrm{RSS}_{n} \mathrm{SR}, \mathrm{RSS}_{n} \mathrm{~S}^{-}, \mathrm{HSS}_{n} \mathrm{~S}^{-}\right.$) can be sources of persulfides. A few polysulfide-containing proteins have been detected, such as SOD1, IL-6, and IgG2 [156]. Recently, the reaction between dibenzyl trisulfide and tetrasulfide with cysteine and glutathione was shown to release $\mathrm{H}_{2} \mathrm{~S}$ with a brief lag-time that was attributed to the formation of persulfides as intermediates [157]. Cysteine trisulfide treatment of cultured cells led to an increase in intracellular cysteine and glutathione persulfides [129].

\subsubsection{Elimination of Disulfide}

The disulfide cystine in the presence of the pyridoxal phosphate-dependent enzymes, CBS and CSE, forms cysteine persulfide, ammonia, and pyruvate. In addition, CSE also catalyzes the formation of homocysteine persulfide from homocystine. Nevertheless, these reactions are limited in vivo $[33,35,37-39,158]$. Disulfides can also suffer a $\beta$-elimination process under alkaline conditions yielding persulfide, a dehydroalanine (2-aminoacrylate) derivative, and water [159-161].

\section{Reactivity of Persulfides with Oxidants}

\subsection{Two-Electron Oxidation}

The enhanced nucleophilicity of persulfides versus thiols is also evidenced by the reactions with two-electron oxidizing electrophiles such as $\mathrm{H}_{2} \mathrm{O}_{2}$ and peroxynitrite. Though the reducing abilities of persulfides have not been fully studied, they seem to be better reductants than the corresponding thiols [162]. The reaction of peroxynitrite with albumin persulfide is one order of magnitude faster $\left((1.2 \pm 0.4) \times 10^{4} \mathrm{M}^{-1} \mathrm{~s}^{-1}\right.$ at $\left.20^{\circ} \mathrm{C}\right)$ than the reduced protein at $\mathrm{pH} 7.4\left((2.7 \pm 0.3) \times 10^{3} \mathrm{M}^{-1} \mathrm{~s}^{-1}\right)$ [28]. Furthermore, it was observed that, under certain conditions, $\mathrm{H}_{2} \mathrm{O}_{2}$ did not react with glutathione but rapidly reacted with glutathione persulfide [33]. Analogously to the reaction of $\mathrm{H}_{2} \mathrm{O}_{2}$ with thiols that 
forms sulfenic acid (RSOH), the reaction with persulfides is expected to produce perthiosulfenic acid (RSSOH). In fact, density functional theory (DFT) calculations predicted that RSSH can be readily oxidized to RSSOH. The reaction of $\mathrm{H}_{2} \mathrm{O}_{2}$ with the persulfide model ethyldisulfane (Et-SSH) to form Et-SSOH was $\sim 6.2 \mathrm{kcal} / \mathrm{mol}$ more favorable compared to the oxidation of the corresponding thiol, ethanethiol (Et-SH) to Et-SOH. These calculations also predicted that $\mathrm{RSOH}$ and $\mathrm{RSSOH}$ are reactive towards dimedone to form stable products. Moreover, the oxidation of cysteine persulfide residues to perthiosulfenic acid was observed in tyrosine kinases such as epidemial growth factor receptor (EGFR) in response to NADPH oxidase activation [163]. In the presence of excess oxidant, the perthiosulfenic acid could be oxidized to perthiosulfinic and perthiosulfonic acids ( $\mathrm{RSSO}_{2} \mathrm{H}$ and $\left.\mathrm{RSSO}_{3} \mathrm{H}\right)[20,163]$. These species have been detected in papain, albumin and glutathione peroxidase $[28,125,151]$. It is noteworthy that while sulfinic and sulfonic acids $\left(\mathrm{RSO}_{2} \mathrm{H}\right.$ and $\left.\mathrm{RSO}_{3} \mathrm{H}\right)$ are generally considered irreversible modification products, $\mathrm{RSSO}_{2} \mathrm{H}$ and $\mathrm{RSSO}_{3} \mathrm{H}$ can be reduced to thiols by common reductants such as dithiothreitol and enzymes such as thioredoxin, and they can therefore allow the restoration of the reduced protein. Thus, as it was previously mentioned, persulfides could protect protein thiols $[29,45,46,153]$. The reactions of persulfides with two-electron oxidants are summarized in Scheme 2.

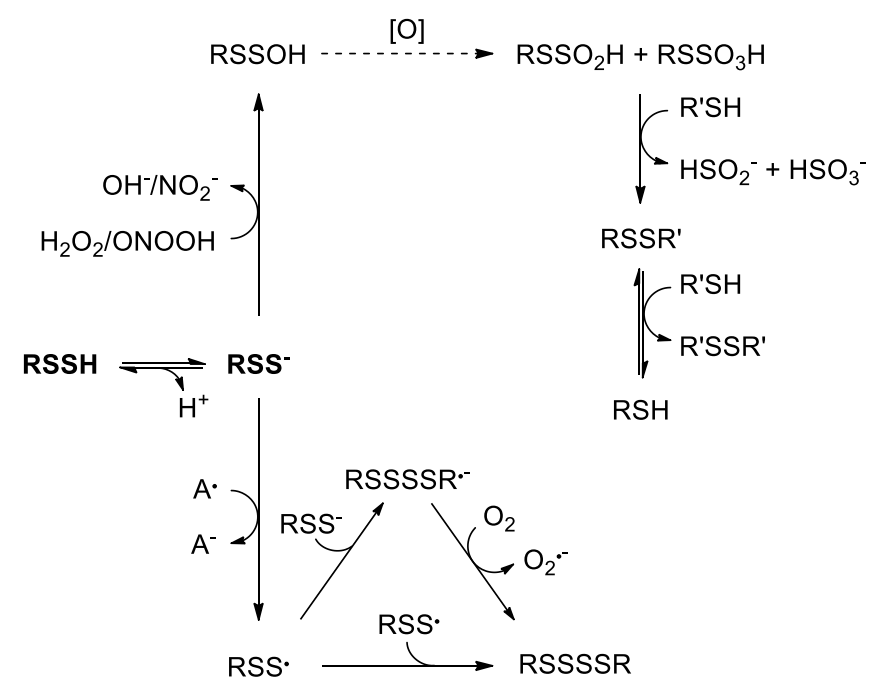

Scheme 2. Persulfide oxidation by reactive species. A $\bullet$ represents a one-electron oxidant. The dashed lines represent processes that are accomplished in more than one step. Protons are sometimes omitted for simplicity.

\subsection{One-Electron Oxidation}

Persulfides have enhanced one-electron reducing capability compared to thiols and $\mathrm{H}_{2} \mathrm{~S}$ [164]. Firstly, persulfides have a lower S-H bond dissociation energy $\left(70 \mathrm{kcal} / \mathrm{mol}\right.$ ) than thiols and $\mathrm{H}_{2} \mathrm{~S}$ $(92 \mathrm{kcal} / \mathrm{mol})[165]$. Secondly, the one-electron reduction potential of persulfides $\left(E^{\circ}\left(\mathrm{RSS}_{\bullet} / \mathrm{RSS}^{-}\right)=\right.$ $+0.68 \mathrm{~V})$ is lower than those of thiols $\left(E^{\circ}\left(\mathrm{RS} \bullet, \mathrm{H}^{+} / \mathrm{RSH}\right)=+0.96 \mathrm{~V}\right)$ and $\mathrm{H}_{2} \mathrm{~S}\left(E^{\circ}\left(\mathrm{S}_{\bullet}^{-}, \mathrm{H}^{+} / \mathrm{HS}^{-}\right)=\right.$ $+0.91 \mathrm{~V}$ ) [87]. Finally, the resonance stabilization energy of RSS• is higher than that of RS•, as the unpaired electron in RSS• is delocalized between the two sulfur atoms [124,164]. Hence, compared to thiols and $\mathrm{H}_{2} \mathrm{~S}$, persulfides can be oxidized by weaker oxidants; the one-electron oxidation products RSS• are less oxidizing than RS• and HS•, react more slowly, and possess an inherent stability. In summary, persulfides constitute better reductants than thiols and $\mathrm{H}_{2} \mathrm{~S}$.

The reaction with one-electron oxidants gives rise to RSS• and can occur through hydrogen atom or electron transfer mechanisms [164]. Persulfides can be oxidized by ferric ions and cannot oxidize ferrous ions [166]. Ferricyanide [47], ferric cytochrome $c$ [126,149,167], and metmyoglobin [47] can oxidize persulfides. RSS• is also formed in the reactions with carbon centered radicals [124], peroxyl radicals [164,168], and the nitroxide TEMPOL [47]. These oxidants react more slowly or not at all 
with the corresponding thiols, exemplifying the better reductant character of persulfides. For instance, TEMPOL and metmyoglobin can be reduced by $N$-methoxycarbonyl penicillamine persulfide but not by an analogous thiol, $\mathrm{N}$-acetyl penicillamine [47]. Furthermore, glutathione persulfide was reported to efficiently reduce ferric cytochrome $c$, while glutathione and $\mathrm{H}_{2} \mathrm{~S}$ only slowly reduced it [126]. A theoretical study of the reactions of $\mathrm{HO} \bullet$ towards a set of persulfides proposed that they could occur through disulfide bond cleavage. In this scenario, RSS• would not be formed [169].

Perthiyl radicals rapidly decay forming tetrasulfide species (RSSSSR) with rate constants of 1-6 $\times 10^{9}$ $\mathrm{M}^{-1} \mathrm{~s}^{-1}[47,168,170]$. In fact, dialkyl tetrasulfide was photolytically cleaved to produce the corresponding RSS•, but dimerization rapidly occurred [168]. The efficiency of this reaction could explain why some thermodynamically unfavorable RSS• formation reactions do occur, such as those of TEMPOL and $\mathrm{CH}_{3} \mathrm{SSH}$ [47], $\mathrm{N}$-methoxycarbonyl penicillamine persulfide and ferric cytochrome $c$ [87,149], or RSS ${ }^{-}$and $\mathrm{O}_{2}$ [171,172]. Moreover, the resulting RSSSSR can decompose to form RSSR and $\mathrm{S}_{\mathrm{n}}$ [20].

Perthiyl radicals can react with RSS $^{-}$to give the intermediate RSSSSR $\bullet^{-}$that reacts with $\mathrm{O}_{2}$ to yield $\mathrm{O}_{2} \bullet^{-}$and RSSSSR. However, RSSSSR $\bullet^{-}$have not been experimentally evidenced [173]. Analogously, RSS• and RS ${ }^{-}$react producing RSSSR $\bullet^{-}$[164]. The reactions are summarized in Scheme 2.

Perthiyl radicals, generated via radiolytic reduction of dialkyl trisulfide, were initially reported to react with $\mathrm{O}_{2}$ with a rate constant of $5.1 \times 10^{6} \mathrm{M}^{-1} \mathrm{~s}^{-1}$. Such reaction was proposed to form RSSOO• species with subsequent formation of inorganic sulfate [170], which is analogous to thiyl radicals that initially form RSOO• in reversible processes [174-177]. However, more recent studies suggest that RSS• and $\mathrm{O}_{2}$ do not react. Photolytically produced RSS• exhibited the same decay in absence than in presence of $\mathrm{O}_{2}$ [168]; besides, oxygen consumption was not altered by addition of perthiyl radicals [47]. Furthermore, computational analysis showed that the reaction between RSS• and $\mathrm{O}_{2}$ is endergonic by $16 \mathrm{kcal} / \mathrm{mol}[47]$.

The reaction of RS• and NO• to form S-nitrosothiols (RSNO) has been deeply studied [178]. The expected product from the reaction of RSS• with NO• would be S-nitrosopersulfide (RSSNO); however, these radicals do not appear to react. Experimental approaches to synthesize RSSNO failed, with formation of NO• and tetrasulfide. In addition, a solution generating RSS• did not consume NO• [47]. Considering the weakness of the S-N bond determined by computational analyses $(3-4 \mathrm{kcal} / \mathrm{mol})$ and the high stability of the radicals, RSSNO is unlikely to exist at room temperature $[47,179]$.

To conclude, persulfides are excellent one-electron reductants. In these reactions, relatively stable perthiyl radicals are formed and can undergo different reactions that ultimately yield RSSSSR.

\section{Conclusions}

In the previous sections, we have summarized the properties of hydrogen sulfide and persulfides, with a focus on redox aspects. A rationalization of the interactions of these species with biologically-relevant reactive oxidants requires an understanding of the kinetics of the processes as well as the elucidation of the fates of the oxidation products formed. While it is becoming clear that direct antioxidant scavenging roles cannot be attributed to $\mathrm{H}_{2} \mathrm{~S}$ except under exceptionally high concentrations, many aspects are yet to be understood about persulfides and their rich biochemistry, including their reactions with oxidants.

Author Contributions: All authors wrote and edited the manuscript.

Funding: This work was supported in part by grants from the Comisión Sectorial de Investigación Científica (CSIC) from Universidad de la República (GRUPOS_I+D_2014_C632-348 and I+D_2016_541), from the Agencia Nacional de Investigación e Innovación (ANII) (to Matías N. Möller, FCE_1_2017_1_136043) and from Fondo Vaz Ferreira, Ministerio de Educación y Cultura (to Ernesto Cuevasanta, I/FVF2017/069). Dayana Benchoam and Ernesto Cuevasanta were partially supported by Comisión Académica de Posgrado (CAP) from Universidad de la República and by PEDECIBA (Uruguay).

Conflicts of Interest: The authors declare no conflict of interest. 


\section{References}

1. Beauchamp, R.O.; Bus, J.S.; Popp, J.A.; Boreiko, C.J.; Andjelkovich, D.A. A critical review of the literature on hydrogen sulfide toxicity. Crit. Rev. Toxicol. 1984, 13, 25-97. [CrossRef] [PubMed]

2. Johnson, K.S.; Beehler, C.L.; Sakamoto-Arnold, C.M.; Childress, J.J. In situ measurements of chemical distributions in a deep-sea hydrothermal vent field. Science 1986, 231, 1139-1141. [CrossRef] [PubMed]

3. Olson, K.R.; Straub, K.D. The role of hydrogen sulfide in evolution and the evolution of hydrogen sulfide in metabolism and signaling. Physiology (Bethesda) 2016, 31, 60-72. [CrossRef] [PubMed]

4. Griesbeck, C.; Hauska, G.; Schütz, M. Biological Sulfide Oxidation: Sulfide-Quinone Reductase (SQR), the Primary Reaction. Recent Res. Dev. Microbiol. 2000, 4, 179-203.

5. Mozzarelli, A.; Bettati, S.; Campanini, B.; Salsi, E.; Raboni, S.; Singh, R.; Spyrakis, F.; Kumar, V.P.; Cook, P.F. The multifaceted pyridoxal 5'-phosphate-dependent O-acetylserine sulfhydrylase. Biochim. Biophys. Acta 2011, 1814, 1497-1510. [CrossRef] [PubMed]

6. Barton, L.L.; Fardeau, M.-L.; Fauque, G.D. Hydrogen sulfide: A toxic gas produced by dissimilatory sulfate and sulfur reduction and consumed by microbial oxidation. Met. Ions Life Sci. 2014, 14, 237-277. [PubMed]

7. Cooper, C.E.; Brown, G.C. The inhibition of mitochondrial cytochrome oxidase by the gases carbon monoxide, nitric oxide, hydrogen cyanide and hydrogen sulfide: Chemical mechanism and physiological significance. J. Bioenerg. Biomembr. 2008, 40, 533-539. [CrossRef] [PubMed]

8. Reiffenstein, R.J.; Hulbert, W.C.; Roth, S.H. Toxicology of hydrogen sulfide. Annu. Rev. Pharmacol. Toxicol. 1992, 32, 109-134. [CrossRef] [PubMed]

9. Grieshaber, M.K.; Völkel, S. Animal adaptations for tolerance and exploitation of poisonous sulfide. Annu. Rev. Physiol. 1998, 60, 33-53. [CrossRef]

10. Leschelle, X.; Goubern, M.; Andriamihaja, M.; Blottière, H.M.; Couplan, E.; Gonzalez-Barroso, M.-D.-M.; Petit, C.; Pagniez, A.; Chaumontet, C.; Mignotte, B.; et al. Adaptative metabolic response of human colonic epithelial cells to the adverse effects of the luminal compound sulfide. Biochim. Biophys. Acta 2005, 1725, 201-212. [CrossRef]

11. Mathai, J.C.; Missner, A.; Kügler, P.; Saparov, S.M.; Zeidel, M.L.; Lee, J.K.; Pohl, P. No facilitator required for membrane transport of hydrogen sulfide. Proc. Natl. Acad. Sci. USA 2009, 106, 16633-16638. [CrossRef] [PubMed]

12. Cuevasanta, E.; Denicola, A.; Alvarez, B.; Möller, M.N. Solubility and permeation of hydrogen sulfide in lipid membranes. PLoS ONE 2012, 7, e34562. [CrossRef] [PubMed]

13. Riahi, S.; Rowley, C.N. Why can hydrogen sulfide permeate cell membranes? J. Am. Chem. Soc. 2014, 136, 15111-15113. [CrossRef] [PubMed]

14. Goubern, M.; Andriamihaja, M.; Nübel, T.; Blachier, F.; Bouillaud, F. Sulfide, the first inorganic substrate for human cells. FASEB J. 2007, 21, 1699-1706. [CrossRef]

15. Kabil, O.; Vitvitsky, V.; Xie, P.; Banerjee, R. The quantitative significance of the transsulfuration enzymes for $\mathrm{H}_{2} \mathrm{~S}$ production in murine tissues. Antioxid. Redox Signal. 2011, 15, 363-372. [CrossRef]

16. Fromageot, C. Oxidation of Organic Sulfur in Animals. In Advances in Enzymology and Related Areas of Molecular Biology; John Wiley \& Sons, Ltd.: Hoboken, NJ, USA, 1947; pp. 369-407. ISBN 978-0-470-12252-5.

17. Kruszyna, H.; Kruszyna, R.; Smith, R.P. Cyanide and sulfide interact with nitrogenous compounds to influence the relaxation of various smooth muscles. Proc. Soc. Exp. Biol. Med. 1985, 179, 44-49. [CrossRef]

18. Abe, K.; Kimura, H. The possible role of hydrogen sulfide as an endogenous neuromodulator. J. Neurosci. 1996, 16, 1066-1071. [CrossRef]

19. Hosoki, R.; Matsuki, N.; Kimura, H. The possible role of hydrogen sulfide as an endogenous smooth muscle relaxant in synergy with nitric oxide. Biochem. Biophys. Res. Commun. 1997, 237, 527-531. [CrossRef]

20. Filipovic, M.R.; Zivanovic, J.; Alvarez, B.; Banerjee, R. Chemical Biology of $\mathrm{H}_{2} \mathrm{~S}$ Signaling through Persulfidation. Chem. Rev. 2018, 118, 1253-1337. [CrossRef]

21. Whiteman, M.; Armstrong, J.S.; Chu, S.H.; Jia-Ling, S.; Wong, B.-S.; Cheung, N.S.; Halliwell, B.; Moore, P.K. The novel neuromodulator hydrogen sulfide: An endogenous peroxynitrite "scavenger"? J. Neurochem. 2004, 90, 765-768. [CrossRef]

22. Kimura, Y.; Kimura, H. Hydrogen sulfide protects neurons from oxidative stress. FASEB J. 2004, 18, $1165-1167$. [CrossRef] [PubMed] 
23. Whiteman, M.; Cheung, N.S.; Zhu, Y.-Z.; Chu, S.H.; Siau, J.L.; Wong, B.S.; Armstrong, J.S.; Moore, P.K. Hydrogen sulphide: A novel inhibitor of hypochlorous acid-mediated oxidative damage in the brain? Biochem. Biophys. Res. Commun. 2005, 326, 794-798. [CrossRef] [PubMed]

24. Yonezawa, D.; Sekiguchi, F.; Miyamoto, M.; Taniguchi, E.; Honjo, M.; Masuko, T.; Nishikawa, H.; Kawabata, A. A protective role of hydrogen sulfide against oxidative stress in rat gastric mucosal epithelium. Toxicology 2007, 241, 11-18. [CrossRef]

25. Laggner, H.; Muellner, M.K.; Schreier, S.; Sturm, B.; Hermann, M.; Exner, M.; Gmeiner, B.M.K.; Kapiotis, S. Hydrogen sulphide: A novel physiological inhibitor of LDL atherogenic modification by HOCl. Free Radic. Res. 2007, 41, 741-747. [CrossRef] [PubMed]

26. Jha, S.; Calvert, J.W.; Duranski, M.R.; Ramachandran, A.; Lefer, D.J. Hydrogen sulfide attenuates hepatic ischemia-reperfusion injury: Role of antioxidant and antiapoptotic signaling. Am. J. Physiol. Heart Circ. Physiol. 2008, 295, H801-H806. [CrossRef]

27. Carballal, S.; Trujillo, M.; Cuevasanta, E.; Bartesaghi, S.; Möller, M.N.; Folkes, L.K.; García-Bereguiaín, M.A.; Gutiérrez-Merino, C.; Wardman, P.; Denicola, A.; et al. Reactivity of hydrogen sulfide with peroxynitrite and other oxidants of biological interest. Free Radic. Biol. Med. 2011, 50, 196-205. [CrossRef] [PubMed]

28. Cuevasanta, E.; Lange, M.; Bonanata, J.; Coitiño, E.L.; Ferrer-Sueta, G.; Filipovic, M.R.; Alvarez, B. Reaction of hydrogen sulfide with disulfide and sulfenic acid to form the strongly nucleophilic persulfide. J. Biol. Chem. 2015, 290, 26866-26880. [CrossRef] [PubMed]

29. Wedmann, R.; Onderka, C.; Wei, S.; Szijártó, I.A.; Miljkovic, J.L.; Mitrovic, A.; Lange, M.; Savitsky, S.; Yadav, P.K.; Torregrossa, R.; et al. Improved tag-switch method reveals that thioredoxin acts as depersulfidase and controls the intracellular levels of protein persulfidation. Chem. Sci. 2016, 7, 3414-3426. [CrossRef]

30. Kessler, D. Enzymatic activation of sulfur for incorporation into biomolecules in prokaryotes. FEMS Microbiol. Rev. 2006, 30, 825-840. [CrossRef]

31. Pandey, A.; Pain, J.; Ghosh, A.K.; Dancis, A.; Pain, D. Fe-S cluster biogenesis in isolated mammalian mitochondria: Coordinated use of persulfide sulfur and iron and requirements for GTP, NADH, and ATP. J. Biol. Chem. 2015, 290, 640-657. [CrossRef]

32. Cuevasanta, E.; Möller, M.N.; Alvarez, B. Biological chemistry of hydrogen sulfide and persulfides. Arch. Biochem. Biophys. 2017, 617, 9-25. [CrossRef] [PubMed]

33. Ida, T.; Sawa, T.; Ihara, H.; Tsuchiya, Y.; Watanabe, Y.; Kumagai, Y.; Suematsu, M.; Motohashi, H.; Fujii, S.; Matsunaga, T.; et al. Reactive cysteine persulfides and S-polythiolation regulate oxidative stress and redox signaling. Proc. Natl. Acad. Sci. USA 2014, 111, 7606-7611. [CrossRef] [PubMed]

34. Hylin, J.W.; Wood, J.L. Enzymatic formation of polysulfides from mercaptopyruvate. J. Biol. Chem. 1959, 234, 2141-2144. [PubMed]

35. Yadav, P.K.; Martinov, M.; Vitvitsky, V.; Seravalli, J.; Wedmann, R.; Filipovic, M.R.; Banerjee, R. Biosynthesis and reactivity of cysteine persulfides in signaling. J. Am. Chem. Soc. 2016, 138, 289-299. [CrossRef] [PubMed]

36. Cavallini, D.; De Marco, C.; Mondovi, B. Cleavage of cystine by a pyridoxal model. Arch. Biochem. Biophys. 1960, 87, 281-288. [CrossRef]

37. Cavallini, D.; Mondovi, B.; De Marco, C.; Sciosciasantoro, A. Inhibitory effect of mercaptoethanol and hypotaurine on the desulfhydration of cysteine by cystathionase. Arch. Biochem. Biophys. 1962, 96, 456-457. [CrossRef]

38. Flavin, M. Microbial transsulfuration: The mechanism of an enzymatic disulfide elimination reaction. J. Biol. Chem. 1962, 237, 768-777.

39. Yamanishi, T.; Tuboi, S. The mechanism of the L-cystine cleavage reaction catalyzed by rat liver gamma-cystathionase. J. Biochem. 1981, 89, 1913-1921. [CrossRef]

40. Szczepkowski, T.W.; Wood, J.L. The cystathionase-rhodanese system. Biochim. Biophys. Acta 1967, 139, 469-478. [CrossRef]

41. Akaike, T.; Ida, T.; Wei, F.-Y.; Nishida, M.; Kumagai, Y.; Alam, M.M.; Ihara, H.; Sawa, T.; Matsunaga, T.; Kasamatsu, S.; et al. Cysteinyl-tRNA synthetase governs cysteine polysulfidation and mitochondrial bioenergetics. Nat. Commun. 2017, 8, 1177. [CrossRef]

42. Mishanina, T.V.; Libiad, M.; Banerjee, R. Biogenesis of reactive sulfur species for signaling by hydrogen sulfide oxidation pathways. Nat. Chem. Biol. 2015, 11, 457-464. [CrossRef] [PubMed] 
43. Valentine, W.N.; Toohey, J.I.; Paglia, D.E.; Nakatani, M.; Brockway, R.A. Modification of erythrocyte enzyme activities by persulfides and methanethiol: Possible regulatory role. Proc. Natl. Acad. Sci. USA 1987, 84, 1394-1398. [CrossRef] [PubMed]

44. Toohey, J.I. Persulfide sulfur is a growth factor for cells defective in sulfur metabolism. Biochem. Cell Biol. 1986, 64, 758-765. [CrossRef] [PubMed]

45. Millikin, R.; Bianco, C.L.; White, C.; Saund, S.S.; Henriquez, S.; Sosa, V.; Akaike, T.; Kumagai, Y.; Soeda, S.; Toscano, J.P.; et al. The chemical biology of protein hydropersulfides: Studies of a possible protective function of biological hydropersulfide generation. Free Radic. Biol. Med. 2016, 97, 136-147. [CrossRef] [PubMed]

46. Ono, K.; Akaike, T.; Sawa, T.; Kumagai, Y.; Wink, D.A.; Tantillo, D.J.; Hobbs, A.J.; Nagy, P.; Xian, M.; Lin, J.; et al. Redox chemistry and chemical biology of $\mathrm{H}_{2} \mathrm{~S}$, hydropersulfides, and derived species: Implications of their possible biological activity and utility. Free Radic. Biol. Med. 2014, 77, 82-94. [CrossRef] [PubMed]

47. Bianco, C.L.; Chavez, T.A.; Sosa, V.; Saund, S.S.; Nguyen, Q.N.N.; Tantillo, D.J.; Ichimura, A.S.; Toscano, J.P.; Fukuto, J.M. The chemical biology of the persulfide (RSSH)/perthiyl (RSS.) redox couple and possible role in biological redox signaling. Free Radic. Biol. Med. 2016, 101, 20-31. [CrossRef] [PubMed]

48. Ezerina, D.; Takano, Y.; Hanaoka, K.; Urano, Y.; Dick, T.P. N-Acetyl Cysteine Functions as a Fast-Acting Antioxidant by Triggering Intracellular $\mathrm{H}_{2} \mathrm{~S}$ and Sulfane Sulfur Production. Cell Chem. Biol. 2018, 25, 447-459.e4. [CrossRef]

49. Agency for Toxic Substances and Disease Registry (ATSDR). Toxicological Profile for Hydrogen Sulfide/Carbonyl Sulfide; U.S. Department of Health and Human Services, Public Health Service: Atlanta, GA, USA, 2016.

50. Bondi, A. van der Waals Volumes and Radii. J. Phys. Chem. 1964, 68, 441-451. [CrossRef]

51. Riahi, S.; Rowley, C.N. Solvation of Hydrogen Sulfide in Liquid Water and at the Water-Vapor Interface Using a Polarizable Force Field. J. Phys. Chem. B 2014, 118, 1373-1380. [CrossRef]

52. Fogg, P.G.T.; Young, C.L. Hydrogen Sulfide, Deuterium Sulfide and Hydrogen Selenide; Pergamon Press: Oxford, UK, 1988; Volume 32, ISBN 978-0-08-032481-4.

53. Hughes, M.N.; Centelles, M.N.; Moore, K.P. Making and working with hydrogen sulfide: The chemistry and generation of hydrogen sulfide in vitro and its measurement in vivo: A review. Free Radic. Biol. Med. 2009, 47, 1346-1353. [CrossRef]

54. Singh, S.; Padovani, D.; Leslie, R.A.; Chiku, T.; Banerjee, R. Relative contributions of cystathionine beta-synthase and gamma-cystathionase to $\mathrm{H}_{2} \mathrm{~S}$ biogenesis via alternative trans-sulfuration reactions. J. Biol. Chem. 2009, 284, 22457-22466. [CrossRef] [PubMed]

55. Mudd, S.H.; Skovby, F.; Levy, H.L.; Pettigrew, K.D.; Wilcken, B.; Pyeritz, R.E.; Andria, G.; Boers, G.H.; Bromberg, I.L.; Cerone, R. The natural history of homocystinuria due to cystathionine beta-synthase deficiency. Am. J. Hum. Genet. 1985, 37, 1-31. [PubMed]

56. Shibuya, N.; Tanaka, M.; Yoshida, M.; Ogasawara, Y.; Togawa, T.; Ishii, K.; Kimura, H. 3-Mercaptopyruvate sulfurtransferase produces hydrogen sulfide and bound sulfane sulfur in the brain. Antioxid. Redox Signal. 2009, 11, 703-714. [CrossRef] [PubMed]

57. Jackson, M.R.; Melideo, S.L.; Jorns, M.S. Human sulfide:quinone oxidoreductase catalyzes the first step in hydrogen sulfide metabolism and produces a sulfane sulfur metabolite. Biochemistry 2012, 51, 6804-6815. [CrossRef] [PubMed]

58. Libiad, M.; Yadav, P.K.; Vitvitsky, V.; Martinov, M.; Banerjee, R. Organization of the human mitochondrial hydrogen sulfide oxidation pathway. J. Biol. Chem. 2014, 289, 30901-30910. [CrossRef] [PubMed]

59. Landry, A.P.; Ballou, D.P.; Banerjee, R. $\mathrm{H}_{2} \mathrm{~S}$ oxidation by nanodisc-embedded human sulfide quinone oxidoreductase. J. Biol. Chem. 2017, 292, 11641-11649. [CrossRef] [PubMed]

60. Vitvitsky, V.; Yadav, P.K.; Kurthen, A.; Banerjee, R. Sulfide oxidation by a noncanonical pathway in red blood cells generates thiosulfate and polysulfides. J. Biol. Chem. 2015, 290, 8310-8320. [CrossRef] [PubMed]

61. Bostelaar, T.; Vitvitsky, V.; Kumutima, J.; Lewis, B.E.; Yadav, P.K.; Brunold, T.C.; Filipovic, M.; Lehnert, N.; Stemmler, T.L.; Banerjee, R. Hydrogen Sulfide Oxidation by Myoglobin. J. Am. Chem. Soc. 2016, 138, 8476-8488. [CrossRef]

62. Ash-Bernal, R.; Wise, R.; Wright, S.M. Acquired methemoglobinemia: A retrospective series of 138 cases at 2 teaching hospitals. Medicine (Baltimore) 2004, 83, 265-273. [CrossRef]

63. Olson, K.R.; DeLeon, E.R.; Liu, F. Controversies and conundrums in hydrogen sulfide biology. Nitric Oxide 2014, 41, 11-26. [CrossRef] 
64. Furne, J.; Saeed, A.; Levitt, M.D. Whole tissue hydrogen sulfide concentrations are orders of magnitude lower than presently accepted values. Am. J. Physiol. Regul. Integr. Comp. Physiol. 2008, 295, R1479-R1485. [CrossRef] [PubMed]

65. Levitt, M.D.; Abdel-Rehim, M.S.; Furne, J. Free and acid-labile hydrogen sulfide concentrations in mouse tissues: Anomalously high free hydrogen sulfide in aortic tissue. Antioxid. Redox Signal. 2011, 15, 373-378. [CrossRef] [PubMed]

66. Vitvitsky, V.; Kabil, O.; Banerjee, R. High Turnover Rates for Hydrogen Sulfide Allow for Rapid Regulation of Its Tissue Concentrations. Antioxid. Redox Signal. 2012, 17, 22-31. [CrossRef] [PubMed]

67. Yang, G.; Wu, L.; Jiang, B.; Yang, W.; Qi, J.; Cao, K.; Meng, Q.; Mustafa, A.K.; Mu, W.; Zhang, S.; et al. H2 $\mathrm{H}_{2}$ as a physiologic vasorelaxant: Hypertension in mice with deletion of cystathionine gamma-lyase. Science 2008, 322, 587-590. [CrossRef] [PubMed]

68. Predmore, B.L.; Lefer, D.J. Development of hydrogen sulfide-based therapeutics for cardiovascular disease. J. Cardiovasc. Transl. Res. 2010, 3, 487-498. [CrossRef] [PubMed]

69. Elsey, D.J.; Fowkes, R.C.; Baxter, G.F. Regulation of cardiovascular cell function by hydrogen sulfide (H(2)S). Cell Biochem. Funct. 2010, 28, 95-106. [CrossRef] [PubMed]

70. Elrod, J.W.; Calvert, J.W.; Morrison, J.; Doeller, J.E.; Kraus, D.W.; Tao, L.; Jiao, X.; Scalia, R.; Kiss, L.; Szabo, C.; et al. Hydrogen sulfide attenuates myocardial ischemia-reperfusion injury by preservation of mitochondrial function. Proc. Natl. Acad. Sci. USA 2007, 104, 15560-15565. [CrossRef]

71. Shen, Y.; Shen, Z.; Luo, S.; Guo, W.; Zhu, Y.Z. The Cardioprotective Effects of Hydrogen Sulfide in Heart Diseases: From Molecular Mechanisms to Therapeutic Potential. Oxid. Med. Cell. Longev. 2015, 2015, 925167. [CrossRef]

72. Szabó, C.; Papapetropoulos, A. Hydrogen sulphide and angiogenesis: Mechanisms and applications. Br. J. Pharmacol. 2011, 164, 853-865. [CrossRef]

73. Fang, L.; Li, H.; Tang, C.; Geng, B.; Qi, Y.; Liu, X. Hydrogen sulfide attenuates the pathogenesis of pulmonary fibrosis induced by bleomycin in rats. Can. J. Physiol. Pharmacol. 2009, 87, 531-538. [CrossRef]

74. Chen, Y.; Wang, R. The message in the air: Hydrogen sulfide metabolism in chronic respiratory diseases. Respir. Physiol. Neurobiol. 2012, 184, 130-138. [CrossRef] [PubMed]

75. Zeng, T.; Zhang, C.-L.; Zhu, Z.-P.; Yu, L.-H.; Zhao, X.-L.; Xie, K.-Q. Diallyl trisulfide (DATS) effectively attenuated oxidative stress-mediated liver injury and hepatic mitochondrial dysfunction in acute ethanol-exposed mice. Toxicology 2008, 252, 86-91. [CrossRef] [PubMed]

76. Bhatia, M. $\mathrm{H}_{2} \mathrm{~S}$ and Inflammation: An Overview. Handb. Exp. Pharmacol. 2015, 230, 165-180. [PubMed]

77. Ang, A.D.; Rivers-Auty, J.; Hegde, A.; Ishii, I.; Bhatia, M. The effect of CSE gene deletion in caerulein-induced acute pancreatitis in the mouse. Am. J. Physiol. Gastrointest. Liver Physiol. 2013, 305, G712-G721. [CrossRef] [PubMed]

78. Zhang, H.; Zhi, L.; Moore, P.K.; Bhatia, M. Role of hydrogen sulfide in cecal ligation and puncture-induced sepsis in the mouse. Am. J. Physiol. Lung Cell Mol. Physiol. 2006, 290, L1193-L1201. [CrossRef] [PubMed]

79. Liu, Y.; Kalogeris, T.; Wang, M.; Zuidema, M.Y.; Wang, Q.; Dai, H.; Davis, M.J.; Hill, M.A.; Korthuis, R.J. Hydrogen sulfide preconditioning or neutrophil depletion attenuates ischemia-reperfusion-induced mitochondrial dysfunction in rat small intestine. Am. J. Physiol. Gastrointest. Liver Physiol. 2012, 302, G44-G54. [CrossRef] [PubMed]

80. Mard, S.A.; Neisi, N.; Solgi, G.; Hassanpour, M.; Darbor, M.; Maleki, M. Gastroprotective effect of NaHS against mucosal lesions induced by ischemia-reperfusion injury in rat. Dig. Dis. Sci. 2012, 57, 1496-1503. [CrossRef]

81. Medeiros, J.V.R.; Bezerra, V.H.; Gomes, A.S.; Barbosa, A.L.R.; Lima-Júnior, R.C.P.; Soares, P.M.G.; Brito, G.A.C.; Ribeiro, R.A.; Cunha, F.Q.; Souza, M.H.L.P. Hydrogen Sulfide Prevents Ethanol-Induced Gastric Damage in Mice: Role of ATP-Sensitive Potassium Channels and Capsaicin-Sensitive Primary Afferent Neurons. J. Pharmacol. Exp. Ther. 2009, 330, 764-770. [CrossRef]

82. Xie, L.; Gu, Y.; Wen, M.; Zhao, S.; Wang, W.; Ma, Y.; Meng, G.; Han, Y.; Wang, Y.; Liu, G.; et al. Hydrogen Sulfide Induces Keap1 S-sulfhydration and Suppresses Diabetes-Accelerated Atherosclerosis via Nrf2 Activation. Diabetes 2016, 65, 3171-3184. [CrossRef]

83. Calvert, J.W.; Elston, M.; Nicholson, C.K.; Gundewar, S.; Jha, S.; Elrod, J.W.; Ramachandran, A.; Lefer, D.J. Genetic and pharmacologic hydrogen sulfide therapy attenuates ischemia-induced heart failure in mice. Circulation 2010, 122, 11-19. [CrossRef] 
84. Calvert, J.W.; Jha, S.; Gundewar, S.; Elrod, J.W.; Ramachandran, A.; Pattillo, C.B.; Kevil, C.G.; Lefer, D.J. Hydrogen sulfide mediates cardioprotection through Nrf2 signaling. Circ. Res. 2009, 105, 365-374. [CrossRef] [PubMed]

85. Zhou, X.; An, G.; Chen, J. Inhibitory effects of hydrogen sulphide on pulmonary fibrosis in smoking rats via attenuation of oxidative stress and inflammation. J. Cell. Mol. Med. 2014, 18, 1098-1103. [CrossRef] [PubMed]

86. Sundaresan, M.; Yu, Z.X.; Ferrans, V.J.; Irani, K.; Finkel, T. Requirement for generation of $\mathrm{H}_{2} \mathrm{O}_{2}$ for platelet-derived growth factor signal transduction. Science 1995, 270, 296-299. [CrossRef] [PubMed]

87. Koppenol, W.H.; Bounds, P.L. Signaling by sulfur-containing molecules. Quantitative aspects. Arch. Biochem. Biophys. 2017, 617, 3-8. [CrossRef] [PubMed]

88. Armstrong, D.A.; Huie, R.E.; Koppenol, W.H.; Lymar, S.V.; Merenyi, G.; Neta, P.; Ruscic, B.; Stanbury, D.M.; Steenken, S.; Wardman, P. Standard electrode potentials involving radicals in aqueous solution: Inorganic radicals (IUPAC Technical Report). Pure Appl. Chem. 2015, 87, 1139-1150. [CrossRef]

89. Koppenol, W.H.; Stanbury, D.M.; Bounds, P.L. Electrode potentials of partially reduced oxygen species, from dioxygen to water. Free Radic. Biol. Med. 2010, 49, 317-322. [CrossRef] [PubMed]

90. Hoffmann, M.R. Kinetics and mechanism of oxidation of hydrogen sulfide by hydrogen peroxide in acidic solution. Environ. Sci. Technol. 1977, 11,61-66. [CrossRef]

91. Rabai, G.; Orban, M.; Epstein, I.R. Systematic design of chemical oscillators. 77. A model for the pH-regulated oscillatory reaction between hydrogen peroxide and sulfide ion. J. Phys. Chem. 1992, 96, 5414-5419. [CrossRef]

92. Davies, M.J.; Hawkins, C.L.; Pattison, D.I.; Rees, M.D. Mammalian heme peroxidases: From molecular mechanisms to health implications. Antioxid. Redox Signal. 2008, 10, 1199-1234. [CrossRef]

93. Nagy, P.; Winterbourn, C.C. Rapid reaction of hydrogen sulfide with the neutrophil oxidant hypochlorous acid to generate polysulfides. Chem. Res. Toxicol. 2010, 23, 1541-1543. [CrossRef]

94. Ferrer-Sueta, G.; Campolo, N.; Trujillo, M.; Bartesaghi, S.; Carballal, S.; Romero, N.; Alvarez, B.; Radi, R. Biochemistry of Peroxynitrite and Protein Tyrosine Nitration. Chem. Rev. 2018, 118, 1338-1408. [CrossRef] [PubMed]

95. Cuevasanta, E.; Zeida, A.; Carballal, S.; Wedmann, R.; Morzan, U.N.; Trujillo, M.; Radi, R.; Estrin, D.A.; Filipovic, M.R.; Alvarez, B. Insights into the mechanism of the reaction between hydrogen sulfide and peroxynitrite. Free Radic. Biol. Med. 2015, 80, 93-100. [CrossRef] [PubMed]

96. Filipovic, M.R.; Miljkovic, J.; Allgäuer, A.; Chaurio, R.; Shubina, T.; Herrmann, M.; Ivanovic-Burmazovic, I. Biochemical insight into physiological effects of $\mathrm{H}_{2} \mathrm{~S}$ : Reaction with peroxynitrite and formation of a new nitric oxide donor, sulfinyl nitrite. Biochem. J. 2012, 441, 609-621. [CrossRef] [PubMed]

97. Das, T.N.; Huie, R.E.; Neta, P.; Padmaja, S. Reduction potential of the sulfhydryl radical: pulse radiolysis and laser flash photolysis studies of the formation and reactions of $\cdot \mathrm{SH}$ and $\mathrm{HSSH} \cdot$ - In aqueous solutions. J. Phys. Chem. A 1999, 103, 5221-5226. [CrossRef]

98. Mills, G.; Schmidt, K.H.; Matheson, M.S.; Meisel, D. Thermal and photochemical reactions of sulfhydryl radicals. Implications for colloid photocorrosion. J. Phys. Chem. 1987, 91, 1590-1596. [CrossRef]

99. Creutz, C.; Sutin, N. Kinetics of the reactions of sodium dithionite with dioxygen and hydrogen peroxide. Inorg. Chem. 1974, 13, 2041-2043. [CrossRef]

100. Chen, K.Y.; Morris, J.C. Kinetics of oxidation of aqueous sulfide by O2. Environ. Sci. Technol. 1972, 6, 529-537. [CrossRef]

101. O'Brien, D.J.; Birkner, F.B. Kinetics of oxygenation of reduced sulfur species in aqueous solution. Environ. Sci. Technol. 1977, 11, 1114-1120. [CrossRef]

102. Wedmann, R.; Bertlein, S.; Macinkovic, I.; Böltz, S.; Miljkovic, J.L.; Muñoz, L.E.; Herrmann, M.; Filipovic, M.R. Working with " $\mathrm{H}_{2} \mathrm{~S}^{\prime}$ : Facts and apparent artifacts. Nitric Oxide 2014, 41, 85-96. [CrossRef]

103. Karmann, W.; Meissner, G.; Henglein, A. Pulsradiolyse des Schwefelwasserstoffs in wäßriger Lösung. Zeitschrift für Naturforschung B 1967, 22, 273-282. [CrossRef]

104. Olson, K.R.; Gao, Y.; DeLeon, E.R.; Arif, M.; Arif, F.; Arora, N.; Straub, K.D. Catalase as a sulfide-sulfur oxido-reductase: An ancient (and modern?) regulator of reactive sulfur species (RSS). Redox Biol. 2017, 12, 325-339. [CrossRef] [PubMed] 
105. Pálinkás, Z.; Furtmüller, P.G.; Nagy, A.; Jakopitsch, C.; Pirker, K.F.; Magierowski, M.; Jasnos, K.; Wallace, J.L.; Obinger, C.; Nagy, P. Interactions of hydrogen sulfide with myeloperoxidase. Br. J. Pharmacol. 2015, 172, 1516-1532. [CrossRef] [PubMed]

106. Garai, D.; Ríos-González, B.B.; Furtmüller, P.G.; Fukuto, J.M.; Xian, M.; López-Garriga, J.; Obinger, C.; Nagy, P. Mechanisms of myeloperoxidase catalyzed oxidation of $\mathrm{H}_{2} \mathrm{~S}$ by $\mathrm{H}_{2} \mathrm{O}_{2}$ or $\mathrm{O}_{2}$ to produce potent protein Cys-polysulfide-inducing species. Free Radic. Biol. Med. 2017, 113, 551-563. [CrossRef] [PubMed]

107. Boubeta, F.M.; Bieza, S.A.; Bringas, M.; Estrin, D.A.; Boechi, L.; Bari, S.E. Mechanism of Sulfide Binding by Ferric Hemeproteins. Inorg. Chem. 2018, 57, 7591-7600. [CrossRef] [PubMed]

108. Kraus, D.W.; Wittenberg, J.B. Hemoglobins of the Lucina pectinata/bacteria symbiosis. I. Molecular properties, kinetics and equilibria of reactions with ligands. J. Biol. Chem. 1990, 265, 16043-16053.

109. Vitvitsky, V.; Yadav, P.K.; An, S.; Seravalli, J.; Cho, U.-S.; Banerjee, R. Structural and Mechanistic Insights into Hemoglobin-catalyzed Hydrogen Sulfide Oxidation and the Fate of Polysulfide Products. J. Biol. Chem. 2017, 292, 5584-5592. [CrossRef] [PubMed]

110. Jensen, B.; Fago, A. Reactions of ferric hemoglobin and myoglobin with hydrogen sulfide under physiological conditions. J. Inorg. Biochem. 2018, 182, 133-140. [CrossRef]

111. Vitvitsky, V.; Miljkovic, J.L.; Bostelaar, T.; Adhikari, B.; Yadav, P.K.; Steiger, A.K.; Torregrossa, R.; Pluth, M.D.; Whiteman, M.; Banerjee, R.; et al. Cytochrome c Reduction by $\mathrm{H}_{2} \mathrm{~S}$ Potentiates Sulfide Signaling. ACS Chem. Biol. 2018, 13, 2300-2307. [CrossRef]

112. Ríos-González, B.B.; Román-Morales, E.M.; Pietri, R.; López-Garriga, J. Hydrogen sulfide activation in hemeproteins: The sulfheme scenario. J. Inorg. Biochem. 2014, 133, 78-86. [CrossRef]

113. Arbelo-Lopez, H.D.; Simakov, N.A.; Smith, J.C.; Lopez-Garriga, J.; Wymore, T. Homolytic Cleavage of Both Heme-Bound Hydrogen Peroxide and Hydrogen Sulfide Leads to the Formation of Sulfheme. J. Phys. Chem. B 2016, 120, 7319-7331. [CrossRef]

114. Searcy, D.G.; Whitehead, J.P.; Maroney, M.J. Interaction of Cu, Zn superoxide dismutase with hydrogen sulfide. Arch. Biochem. Biophys. 1995, 318, 251-263. [CrossRef] [PubMed]

115. Olson, K.R.; Gao, Y.; Arif, F.; Arora, K.; Patel, S.; DeLeon, E.R.; Sutton, T.R.; Feelisch, M.; Cortese-Krott, M.M.; Straub, K.D. Metabolism of hydrogen sulfide $\left(\mathrm{H}_{2} \mathrm{~S}\right)$ and Production of Reactive Sulfur Species (RSS) by superoxide dismutase. Redox Biol. 2018, 15, 74-85. [CrossRef] [PubMed]

116. Filipovic, M.R.; Miljkovic, J.L.; Nauser, T.; Royzen, M.; Klos, K.; Shubina, T.; Koppenol, W.H.; Lippard, S.J.; Ivanović-Burmazović, I. Chemical characterization of the smallest S-nitrosothiol, HSNO; cellular cross-talk of $\mathrm{H}_{2} \mathrm{~S}$ and S-nitrosothiols. J. Am. Chem. Soc. 2012, 134, 12016-12027. [CrossRef]

117. Cortese-Krott, M.M.; Kuhnle, G.G.C.; Dyson, A.; Fernandez, B.O.; Grman, M.; DuMond, J.F.; Barrow, M.P.; McLeod, G.; Nakagawa, H.; Ondrias, K.; et al. Key bioactive reaction products of the $\mathrm{NO} / \mathrm{H}_{2} \mathrm{~S}$ interaction are S/N-hybrid species, polysulfides, and nitroxyl. Proc. Natl. Acad. Sci. USA 2015, 112, E4651-E4660. [CrossRef] [PubMed]

118. Wedmann, R.; Ivanovic-Burmazovic, I.; Filipovic, M.R. Nitrosopersulfide (SSNO ${ }^{-}$) decomposes in the presence of sulfide, cyanide or glutathione to give $\mathrm{HSNO} / \mathrm{SNO}^{-}$: Consequences for the assumed role in cell signalling. Interface Focus 2017, 7, 20160139. [CrossRef]

119. Wedmann, R.; Zahl, A.; Shubina, T.E.; Dürr, M.; Heinemann, F.W.; Bugenhagen, B.E.C.; Burger, P.; Ivanovic-Burmazovic, I.; Filipovic, M.R. Does Perthionitrite $\left(\mathrm{SSNO}^{-}\right)$Account for Sustained Bioactivity of NO? A (Bio)chemical Characterization. Inorg. Chem. 2015, 54, 9367-9380. [CrossRef]

120. Cortese-Krott, M.M.; Butler, A.R.; Woollins, J.D.; Feelisch, M. Inorganic sulfur-nitrogen compounds: From gunpowder chemistry to the forefront of biological signaling. Dalton Trans. 2016, 45, 5908-5919. [CrossRef]

121. Marcolongo, J.P.; Zeida, A.; Slep, L.D.; Olabe, J.A. Chapter Seven-Thionitrous Acid/Thionitrite and Perthionitrite Intermediates in the "Crosstalk" of $\mathrm{NO}$ and $\mathrm{H}_{2} \mathrm{~S}$. In Advances in Inorganic Chemistry; van Eldik, R., Hubbard, C.D., Eds.; Inorganic Reaction Mechanisms; Academic Press: Cambridge, MA, USA, 2017; Volume 70, pp. 277-309.

122. Portillo-Ledesma, S.; Sardi, F.; Manta, B.; Tourn, M.V.; Clippe, A.; Knoops, B.; Alvarez, B.; Coitiño, E.L.; Ferrer-Sueta, G. Deconstructing the catalytic efficiency of peroxiredoxin-5 peroxidatic cysteine. Biochemistry 2014, 53, 6113-6125. [CrossRef]

123. Wood, J.L. Sulfane sulfur. Meth. Enzymol. 1987, 143, 25-29.

124. Everett, S.A.; Folkes, L.K.; Wardman, P.; Asmus, K.D. Free-radical repair by a novel perthiol: Reversible hydrogen transfer and perthiyl radical formation. Free Radic. Res. 1994, 20, 387-400. [CrossRef] 
125. Pan, J.; Carroll, K.S. Persulfide reactivity in the detection of protein s-sulfhydration. ACS Chem. Biol. 2013, 8, 1110-1116. [CrossRef] [PubMed]

126. Francoleon, N.E.; Carrington, S.J.; Fukuto, J.M. The reaction of H(2)S with oxidized thiols: Generation of persulfides and implications to H(2)S biology. Arch. Biochem. Biophys. 2011, 516, 146-153. [CrossRef] [PubMed]

127. Park, C.-M.; Johnson, B.A.; Duan, J.; Park, J.-J.; Day, J.J.; Gang, D.; Qian, W.-J.; Xian, M. 9-Fluorenylmethyl (Fm) disulfides: Biomimetic precursors for persulfides. Org. Lett. 2016, 18, 904-907. [CrossRef] [PubMed]

128. Bogdándi, V.; Ida, T.; Sutton, T.R.; Bianco, C.; Ditrói, T.; Koster, G.; Henthorn, H.A.; Minnion, M.; Toscano, J.P.; van der Vliet, A.; et al. Speciation of reactive sulfur species and their reactions with alkylating agents: Do we have any clue about what is present inside the cell? Br. J. Pharmacol. 2019, 176, 646-670. [CrossRef] [PubMed]

129. Bianco, C.L.; Akaike, T.; Ida, T.; Nagy, P.; Bogdandi, V.; Toscano, J.P.; Kumagai, Y.; Henderson, C.F.; Goddu, R.N.; Lin, J.; et al. The reaction of hydrogen sulfide with disulfides: Formation of a stable trisulfide and implications for biological systems. Br. J. Pharmacol. 2019, 176, 671-683. [CrossRef] [PubMed]

130. Fukuto, J.M.; Carrington, S.J.; Tantillo, D.J.; Harrison, J.G.; Ignarro, L.J.; Freeman, B.A.; Chen, A.; Wink, D.A. Small molecule signaling agents: The integrated chemistry and biochemistry of nitrogen oxides, oxides of carbon, dioxygen, hydrogen sulfide, and their derived species. Chem. Res. Toxicol. 2012, 25, 769-793. [CrossRef] [PubMed]

131. Jencks, W.P.; Carriuolo, J. Reactivity of nucleophilic reagents toward esters. J. Am. Chem. Soc. 1960, 82, 1778-1786. [CrossRef]

132. Edwards, J.O.; Pearson, R.G. The factors determining nucleophilic reactivities. J. Am. Chem. Soc. 1962, 84, 16-24. [CrossRef]

133. Kawamura, S.; Nakabayashi, T.; Kitao, T.; Tsurugi, J. Aralkyl hydrodisulfides. VI. The Reaction of Benzhydryl Hydrosulfide with Several Neucleophiles. J. Org. Chem. 1966, 31, 1985-1987. [CrossRef]

134. Bailey, T.S.; Zakharov, L.N.; Pluth, M.D. Understanding hydrogen sulfide storage: Probing conditions for sulfide release from hydrodisulfides. J. Am. Chem. Soc. 2014, 136, 10573-10576. [CrossRef]

135. Kawamura, S.; Otsuji, Y.; Nakabayashi, T.; Kitao, T.; Tsurugi, J. Aralkyl hydrodisulfides. IV. The Reaction of Benzyl Hydrodisulfide with Several Nucleophiles. J. Org. Chem. 1965, 30, 2711-2714. [CrossRef]

136. Tsurugi, J.; Abe, Y.; Nakabayashi, T.; Kawamura, S.; Kitao, T.; Niwa, M. Aralkyl hydrodisulfides. XI. Reaction with amines. J. Org. Chem. 1970, 35, 3263-3266. [CrossRef]

137. Kawamura, S.; Kitao, T.; Nakabayashi, T.; Horii, T.; Tsurugi, J. Aralkyl hydrodisulfides. VIII. Alkaline decomposition and its competition with nucleophiles. J. Org. Chem. 1968, 33, 1179-1181. [CrossRef]

138. Tsurugi, J.; Nakabayashi, T.; Ishihara, T. Aralkyl hydrodisulfides. III. The Reaction with Tertiary Phosphines. J. Org. Chem. 1965, 30, 2707-2710. [CrossRef]

139. Bailey, T.S.; Pluth, M.D. Reactions of isolated persulfides provide insights into the interplay between $\mathrm{H}_{2} \mathrm{~S}$ and persulfide reactivity. Free Radic. Biol. Med. 2015, 89, 662-667. [CrossRef] [PubMed]

140. Hiskey, R.G.; Carroll, F.I. Chemistry of aliphatic disulfides. II. Cyanide cleavage of unsymmetrical disulfides. J. Am. Chem. Soc. 1961, 83, 4644-4647. [CrossRef]

141. Yadav, P.K.; Yamada, K.; Chiku, T.; Koutmos, M.; Banerjee, R. Structure and kinetic analysis of $\mathrm{H}_{2} \mathrm{~S}$ production by human mercaptopyruvate sulfurtransferase. J. Biol. Chem. 2013, 288, 20002-20013. [CrossRef]

142. Sorbo, B. Enzymic transfer of sulfur from mercaptopyruvate to sulfate or sulfinates. Biochim. Biophys. Acta 1957, 24, 324-329. [CrossRef]

143. Hildebrandt, T.M.; Grieshaber, M.K. Three enzymatic activities catalyze the oxidation of sulfide to thiosulfate in mammalian and invertebrate mitochondria. FEBS J. 2008, 275, 3352-3361. [CrossRef]

144. Libiad, M.; Sriraman, A.; Banerjee, R. Polymorphic Variants of Human Rhodanese Exhibit Differences in Thermal Stability and Sulfur Transfer Kinetics. J. Biol. Chem. 2015, 290, 23579-23588. [CrossRef]

145. Kim, S.; Park, S. Structural changes during cysteine desulfurase CsdA and sulfur acceptor CsdE interactions provide insight into the trans-persulfuration. J. Biol. Chem. 2013, 288, 27172-27180. [CrossRef] [PubMed]

146. Aroca, A.; Gotor, C.; Romero, L.C. Hydrogen Sulfide Signaling in Plants: Emerging Roles of Protein Persulfidation. Front. Plant Sci. 2018, 9, 1369. [CrossRef] [PubMed]

147. Dóka, É.; Pader, I.; Bíró, A.; Johansson, K.; Cheng, Q.; Ballagó, K.; Prigge, J.R.; Pastor-Flores, D.; Dick, T.P.; Schmidt, E.E.; et al. A novel persulfide detection method reveals protein persulfide- and polysulfide-reducing functions of thioredoxin and glutathione systems. Sci. Adv. 2016, 2, e1500968. [CrossRef] [PubMed] 
148. Ju, Y.; Wu, L.; Yang, G. Thioredoxin 1 regulation of protein S-desulfhydration. Biochem. Biophys. Rep. 2016, 5, 27-34. [CrossRef] [PubMed]

149. Artaud, I.; Galardon, E. A persulfide analogue of the nitrosothiol SNAP: Formation, characterization and reactivity. ChemBioChem 2014, 15, 2361-2364. [CrossRef] [PubMed]

150. Koike, S.; Nishimoto, S.; Ogasawara, Y. Cysteine persulfides and polysulfides produced by exchange reactions with $\mathrm{H}_{2} \mathrm{~S}$ protect $\mathrm{SH}_{-} \mathrm{SY}_{5} \mathrm{Y}$ cells from methylglyoxal-induced toxicity through $\mathrm{Nrf}_{2}$ activation. Redox Biol. 2017, 12, 530-539. [CrossRef] [PubMed]

151. Zhang, D.; Macinkovic, I.; Devarie-Baez, N.O.; Pan, J.; Park, C.-M.; Carroll, K.S.; Filipovic, M.R.; Xian, M. Detection of protein S-sulfhydration by a tag-switch technique. Angew. Chem. Int. Ed. Engl. 2014, 53, 575-581. [CrossRef]

152. Mishanina, T.V.; Yadav, P.K.; Ballou, D.P.; Banerjee, R. Transient Kinetic Analysis of Hydrogen Sulfide Oxidation Catalyzed by Human Sulfide Quinone Oxidoreductase. J. Biol. Chem. 2015, 290, 25072-25080. [CrossRef]

153. Filipovic, M.R. Persulfidation (S-sulfhydration) and $\mathrm{H}_{2}$ S. Handb. Exp. Pharmacol. 2015, 230, $29-59$.

154. Liu, D.K.; Chang, S.G. Kinetic study of the reaction between cystine and sulfide in alkaline solutions. Can. J. Chem. 1987, 65, 770-774. [CrossRef]

155. Vasas, A.; Dóka, É.; Fábián, I.; Nagy, P. Kinetic and thermodynamic studies on the disulfide-bond reducing potential of hydrogen sulfide. Nitric Oxide 2015, 46, 93-101. [CrossRef] [PubMed]

156. Nielsen, R.W.; Tachibana, C.; Hansen, N.E.; Winther, J.R. Trisulfides in Proteins. Antioxid. Redox Signal. 2010, 15, 67-75. [CrossRef] [PubMed]

157. Bolton, S.G.; Cerda, M.M.; Gilbert, A.K.; Pluth, M.D. Effects of sulfane sulfur content in benzyl polysulfides on thiol-triggered $\mathrm{H}_{2} \mathrm{~S}$ release and cell proliferation. Free Radic. Biol. Med. 2019, 131, 393-398. [CrossRef] [PubMed]

158. Toohey, J.I. Sulfur signaling: Is the agent sulfide or sulfane? Anal. Biochem. 2011, 413, 1-7. [CrossRef] [PubMed]

159. Florence, T.M. Degradation of protein disulphide bonds in dilute alkali. Biochem. J. 1980, 189, 507-520. [CrossRef] [PubMed]

160. Federici, G.; Duprè, S.; Matarese, R.M.; Solinas, S.P.; Cavallini, D. Is the alkaline cleavage of disulfide bonds in peptides an alpha-beta elimination reaction or a hydrolysis? Int. J. Pept. Protein Res. 1977, 10, 185-189. [CrossRef] [PubMed]

161. Jones, A.J.; Helmerhorst, E.; Stokes, G.B. The formation of dehydroalanine residues in alkali-treated insulin and oxidized glutathione. A nuclear-magnetic-resonance study. Biochem. J. 1983, 211, 499-502. [CrossRef] [PubMed]

162. Álvarez, L.; Bianco, C.L.; Toscano, J.P.; Lin, J.; Akaike, T.; Fukuto, J.M. Chemical Biology of Hydropersulfides and Related Species: Possible Roles in Cellular Protection and Redox Signaling. Antioxid. Redox Signal. 2017, 27, 622-633. [CrossRef] [PubMed]

163. Heppner, D.E.; Hristova, M.; Ida, T.; Mijuskovic, A.; Dustin, C.M.; Bogdándi, V.; Fukuto, J.M.; Dick, T.P.; Nagy, P.; Li, J.; et al. Cysteine perthiosulfenic acid (Cys-SSOH): A novel intermediate in thiol-based redox signaling? Redox Biol. 2018, 14, 379-385. [CrossRef]

164. Everett, S.A.; Wardman, P. Perthiols as antioxidants: Radical-scavenging and prooxidative mechanisms. Meth. Enzymol. 1995, 251, 55-69.

165. Benson, S.W. Thermochemistry and kinetics of sulfur-containing molecules and radicals. Chem. Rev. 1978, 78, 23-35. [CrossRef]

166. Kawamura, S.; Abe, Y.; Tsurugi, J. Aralkyl hydrodisulfides. X. Reactions with iron salts. J. Org. Chem. 1969, 34, 3633-3635. [CrossRef]

167. Prütz, W.A. Catalytic reduction of Fe(III)-cytochrome-c involving stable radiolysis products derived from disulphides, proteins and thiols. Int. J. Radiat. Biol. 1992, 61, 593-602. [CrossRef] [PubMed]

168. Chauvin, J.-P.R.; Haidasz, E.A.; Griesser, M.; Pratt, D.A. Polysulfide-1-oxides react with peroxyl radicals as quickly as hindered phenolic antioxidants and do so by a surprising concerted homolytic substitution. Chem. Sci. 2016, 7, 6347-6356. [CrossRef] [PubMed]

169. Anglada, J.M.; Crehuet, R.; Adhikari, S.; Francisco, J.S.; Xia, Y. Reactivity of hydropersulfides toward the hydroxyl radical unraveled: Disulfide bond cleavage, hydrogen atom transfer, and proton-coupled electron transfer. Phys. Chem. Chem. Phys. 2018, 20, 4793-4804. [CrossRef] [PubMed] 
170. Everett, S.A.; Schoeneich, C.; Stewart, J.H.; Asmus, K.D. Perthiyl radicals, trisulfide radical ions, and sulfate formation: A combined photolysis and radiolysis study on redox processes with organic di- and trisulfides. J. Phys. Chem. 1992, 96, 306-314. [CrossRef]

171. Chatterji, T.; Keerthi, K.; Gates, K.S. Generation of reactive oxygen species by a persulfide (BnSSH). Bioorg. Med. Chem. Lett. 2005, 15, 3921-3924. [CrossRef]

172. Saund, S.S.; Sosa, V.; Henriquez, S.; Nguyen, Q.N.N.; Bianco, C.L.; Soeda, S.; Millikin, R.; White, C.; Le, H.; Ono, K.; et al. The chemical biology of hydropersulfides (RSSH): Chemical stability, reactivity and redox roles. Arch. Biochem. Biophys. 2015, 588, 15-24. [CrossRef]

173. Kende, I.; Pickering, T.L.; Tobolsky, A.V. The Dissociation Energy of the Tetrasulfide Linkage. J. Am. Chem. Soc. 1965, 87, 5582-5586. [CrossRef]

174. Quintiliani, M.; Badiello, R.; Tamba, M.; Esfandi, A.; Gorin, G. Radiolysis of glutathione in oxygen-containing solutions of pH7. Int. J. Radiat. Biol. Relat. Stud. Phys. Chem. Med. 1977, 32, 195-202. [CrossRef]

175. Tamba, M.; Simone, G.; Quintiliani, M. Interactions of thiyl free radicals with oxygen: A pulse radiolysis study. Int. J. Radiat. Biol. Relat. Stud. Phys. Chem. Med. 1986, 50, 595-600. [CrossRef] [PubMed]

176. Sevilla, M.D.; Becker, D.; Yan, M. The formation and structure of the sulfoxyl radicals RSO(.), RSOO(.), $\mathrm{RSO} 2($.$) , and \mathrm{RSO} 2 \mathrm{OO}($.$) from the reaction of cysteine, glutathione and penicillamine thiyl radicals with$ molecular oxygen. Int. J. Radiat. Biol. 1990, 57, 65-81. [CrossRef]

177. Zhang, X.; Zhang, N.; Schuchmann, H.-P.; von Sonntag, C. Pulse Radiolysis of 2-Mercaptoethanol in Oxygenated Aqueous Solution. Generation and Reactions of the Thiylperoxyl Radical. J. Phys. Chem. 1994, 98, 6541-6547. [CrossRef]

178. Madej, E.; Folkes, L.K.; Wardman, P.; Czapski, G.; Goldstein, S. Thiyl radicals react with nitric oxide to form S-nitrosothiols with rate constants near the diffusion-controlled limit. Free Radic. Biol. Med. 2008, 44, 2013-2018. [CrossRef] [PubMed]

179. Bailey, T.S.; Henthorn, H.A.; Pluth, M.D. The Intersection of $\mathrm{NO}$ and $\mathrm{H}_{2} \mathrm{~S}$ : Persulfides Generate $\mathrm{NO}$ from Nitrite through Polysulfide Formation. Inorg. Chem. 2016, 55, 12618-12625. [CrossRef] [PubMed]

(C) 2019 by the authors. Licensee MDPI, Basel, Switzerland. This article is an open access article distributed under the terms and conditions of the Creative Commons Attribution (CC BY) license (http:/ / creativecommons.org/licenses/by/4.0/). 